\title{
(Re)layout as a Strategy for Implementing Cleaner Production: Proposal for a Furniture Industry Company
}

\author{
Patrícia Soares Lins ${ }^{1,2, * \mathbb{D}}$, Asher Kiperstok ${ }^{1}$, Rita Dione Araujo Cunha ${ }^{1}$, \\ Áurea Luiza Quixabeira Rosa e Silva Rapôso ${ }^{2,3}\left[\right.$, , Eugenio Andrés Díaz Merino $^{4}$ (i) and Sandro Fábio César ${ }^{1}$ \\ 1 Post-Graduation in Industrial Engineering (PEI), Federal University of Bahia (UFBA), \\ Salvador 40210-630, Brazil; asherkiperstok@gmail.com (A.K.); ritadi@uol.com.br (R.D.A.C.); \\ sfcesarpaz@uol.com.br (S.F.C.) \\ 2 Department of Interior Design Technology, Federal Institute of Alagoas (IFAL), Maceió 57035-660, Brazil; \\ aurea.raposo@ifal.edu.br \\ 3 Post-Graduation Program in Environmental Technology (PPGTEC), Federal Institute of Alagoas (IFAL), \\ Maceió 57035-660, Brazil \\ 4 Post-Graduation Program in Design and Post-Graduation Program in Production Engineering, \\ Federal University of Santa Catarina (UFSC), Florianópolis 88040-900, Brazil; eugenio.merino@ufsc.br \\ * Correspondence: patriciasoares.lins@yahoo.com.br; Tel.: +55-82-99-610-9840
}

check for updates

Citation: Lins, P.S.; Kiperstok, A.; Cunha, R.D.A.; Rapôso, Á.L.Q.R.e.S.; Merino, E.A.D.; César, S.F. (Re)layout as a Strategy for Implementing Cleaner Production: Proposal for a Furniture Industry Company. Sustainability 2021, 13, 13109. https://doi.org/10.3390/su132313109

Academic Editor: João Carlos de Oliveira Matias

Received: 16 October 2021

Accepted: 23 November 2021

Published: 26 November 2021

Publisher's Note: MDPI stays neutral with regard to jurisdictional claims in published maps and institutional affiliations.

Copyright: (c) 2021 by the authors. Licensee MDPI, Basel, Switzerland. This article is an open access article distributed under the terms and conditions of the Creative Commons Attribution (CC BY) license (https:/ / creativecommons.org/licenses/by/ $4.0 /)$.

\begin{abstract}
This article includes the proposal of a (re)layout project as a strategy to implement Cleaner Production (CP) practices, with a furniture manufacturing company in the Brazilian municipality of Palhoça (Santa Catarina, Brazil) as a case study. This work is characterized as applied research, using a multi-methodological approach, being subdivided into two different steps: literature review and case study. The (re)layout project led to an increase of the administrative area by $25.18 \%$, having had a positive impact on the management areas, aiming towards the integration of Environmental Management, ecodesign, Production Planning and Control sectors. The project led to a decrease of the total stock area of raw materials/storage by $70.01 \mathrm{~m}^{2}$, representing a reduction of $25.59 \%$ when compared to the previous area. The project resulted in an increase of the plant production capacity, increasing the production area by $33.33 \%$, thus optimizing areas and sectors, combining those which are inter-related. The byproducts also stood out in the layout mapping, with the areas allocated to byproducts being reduced by $51.69 \%$. Therefore, the Sustainable Development Goals (SDG) were fulfilled. The removal of physical waste and production losses can be achieved from a (re)layout project integrated with CP by optimizing, areas, sectors, flows and processes.
\end{abstract}

Keywords: Cleaner Production (CP); furniture industry; physical arrangement; (re)layout

\section{Introduction}

Cleaner Production (CP) was defined in 1990 by the United Nations Environmental Program (UNEP) as an integrated environmental prevention strategy applied to production processes, products and services with the objective of continuously improving the efficiency of systems while also reducing the risks for human beings and the environment [1]. In the 1990s, UNEP and the United Nations Industrial Development Organization (UNIDO) started the industry support program, promoting the provision of CP services, and Resource Efficient and Cleaner Production (RECP) to support Small and Medium-sized Enterprises (SMEs) to preserve and minimize the use of natural resources, optimizing the economic performance of these resources and improving employability, safety and the well-being of workers and local communities [2].

$\mathrm{CP}$ analyzes a company's production process from a technical, economic and environmental point of view, considering it as a macrosystem capable of converting inputs into products that do not harm nature. CP identifies opportunities for continuous improvement in environmental performance, avoiding higher costs and taking into account a systemic view that allows the interaction of all elements [3]. 
The CP approach promotes integration, besides being preventive and specific to the location being analyzed. It is also related to continuous enhancement processes, optimizing resources and operational, energy and material flows. In addition, it is linked to emission reductions, quality of health and safety in the work environment, to improvements in the quality of products and services, as well as to the optimization of Raw Materials (RM) and minimizing the use of resources. Besides, CP promotes reuse and recycling strategies, reducing waste and toxicity, encouraging the application of organizational measures for changing routines and implementing good environmental practices and reductions at the generating source [4-7].

Studies confirm the relationship between the maturity of project management and the successful implementation of $\mathrm{CP}$, acknowledging that investment strategies on $\mathrm{CP}$ are directly related to improvements on organizational performance [6,7]. Moreover, studies also point out that investments on $\mathrm{CP}$ are linked to greater competitiveness to ensure economic and environmental gains for a more sustainable development, thus contributing towards UN's Sustainable Development Goals (SDG). In this regard, such practices can promote health and wellbeing (SDG 3); innovation, sustainable and efficient industrial infrastructures in terms of the use of resources, technologies and cleaner processes (SDG 9); production and consumption standards that minimize negative impacts to the environment and to humans, thus preventing and reducing waste generation and promoting reuse and recycling of materials and products (SDG 12); as well as protection, recovery and sustainable use of ecosystems (SDG 15) [8-10].

The integration of CP practices in Environmental Management Systems (EMSs) can contribute to a continuous improvement of environmental performance of industrial facilities [11], since the reduction of production waste is connected to the technology employed in the process and the physical production space (layout) as well as to how operations are carried out. The layout represents the form of productive operations and determines the type of process. It consists in the location and physical arrangement of transformation resources (facilities, machines, equipment, materials, information and people), establishing production flows $[12,13]$. The "[ . . ] facility layout is an arrangement of everything needed for the production of goods or delivery of services" [14] (p. 2079). In sum, a (re)layout project consists of the physical (re)positioning and (re)arrangement of these resources in companies, aiming at optimizing processes and for a continuous improvement of the existing space or the rearrangement to another location, and can be used as a strategy for implementing CP.

The optimized layout of industrial facilities can boost and promote performance improvements, leading to greater competitiveness [15] and influencing internal/external process workflows in the value chain [16]. The layout is one of the items assessed in CP implementation reports in the Brazilian National Center of Clean Technologies (CNTL, in Portuguese) that highlights the need of analyzing spaces, deployment plan, operating and equipment practices, use and movement of materials (flow) and internal organization in order to maximize production capacity and eliminate waste [17,18].

The construction and deployment project of furniture manufacturing companies without prior detailed studies on production systems, processes, the planning of facilities and the physical space necessary for the production may require further changes and the readaptation of the layout after production activities have started [19]. Most case studies aim at improving the performance of existing layouts-(re)layout projects-to increase productivity and competitiveness of companies, mainly small businesses which are subject to changes in their location, as they usually do not operate in their own facilities, operating in rented spaces. Therefore, these changes require (re)layout operations for the adaption and continuity of the production activity.

The incapacity of financial investments by SMEs prevents the application of correct environmental practices. However, the use of more efficient machines and equipment, besides investment on training and the implementation of $\mathrm{CP}$ practices, can lead to economic and environmental gains which can help to overcome technical and cultural barriers 
for the application of $\mathrm{CP}$ in small enterprises, thus reducing costs and environmental impacts [20]. Housekeeping techniques for maximizing production capacity, the arrangement of machines and equipment leading to lower flows, besides the change in the physical arrangement (layout) and in the operating conditions, can be integrated [21] for a continuous improvement and optimization of production resources.

The (re)layout project integrated to the $\mathrm{CP}$, as a strategy for the implementation of the CP in SMEs, boosts changes in areas and sectors that promote the optimization of processes and the minimization of production losses. This study aims at corroborating with this hypothesis by analyzing a small furniture manufacturing company in the Brazilian municipality of Palhoça, in Southern Brazil.

The furniture industry is one of the greatest consumers and waste generators of forestbased natural resources, being part of the transformation industry and with a negative impact on the environment $[22,23]$. Therefore, research related to the polluting potential of the furniture sector and the minimization of the environmental impact of the sector are increasingly necessary.

The assessment carried out in furniture industries in Australia on wood waste and the respective discharge costs concluded that, in the period of 1 year, $7-50 \%$ of wood Raw Materials (RM) was wasted, with $65-85 \%$ resulting from sawdust and chips of wood, $15-35 \%$ from mass timber and pieces of wood panels. The costs of these production losses represented 2-8\% of the business carried out [24].

A study on the emissions of Volatile Organic Compounds (VOCs) present in chemical products used in the furniture industry in Zhuhai (China), in the processes of hot gluing edge bands, finishing, surface coating and panting, identified impacts on the health of workers. The study thus recommended the need for changing the use of waterborne products and green coating in controlling the exposure to chemical agents, and in industrial technologies and facilities [25].

In Brazil, studies confirm that the implementation of $\mathrm{CP}$ reduces production losses. In Salvador, in the State of Bahia, the application of $\mathrm{CP}$ in a small furniture manufacturing company led to changes in the design (simplification of the production process, remodeling, redesign, material replacement), aiming at reducing RM losses in the generating source. These procedures resulted in a reduction of $30 \%$ in the amount of RMs, $49 \%$ in waste generation and $36 \%$ in energy consumption [22].

In the municipality of Cariacica (State of Espírito Santo, Brazil), studies demonstrated that over $20 \%$ of solid wood purchased was wasted in the form of woodchips, wood shaving and sawdust, generating costs with illegal discharge [23]. Moreover, research carried out in Natal, in the Brazilian State of Rio Grande do Norte, pointed out that the implementation of $\mathrm{CP}$ led to a greater reuse of MDF sawdust for manufacturing new MDF profiles, thus optimizing the use of materials, with economic benefits and returns to companies, besides operational improvements and pollution reduction [26].

The implementation of $\mathrm{CP}$ practices in the furniture manufacturing industry of doors and partition panels in the Brazilian State of Minas Gerais, focusing on the flow of materials, identified CP opportunities to reduce waste, inputs, water and RMs, resulting in savings of $66 \%$ in water consumption and 3\% in the consumption of RMs. The generation of solid waste was reduced from $23 \%$ to $93 \%$, preventing cutting down 3900 pine trees and reducing $13,100 \mathrm{~kg}$ of carbon dioxide emissions by transporting this material. In this regard, CP was considered as a tool for ecoefficiency and allowed optimizing the consumption of materials and decreasing water and energy waste [27].

Data from the research applied to the furniture manufacturing industry in Brazil identified a high production of wood waste (a noble raw material), especially in SMEs, demonstrating the inefficiency of the production processes carried out. It also highlighted the inefficiency of the layout of facilities, the location and control of stocks, as well as the movement of people and materials. The analysis also emphasized the importance of expanding and combining two areas of knowledge for developing (re)layout projects integrated with the implementation of $\mathrm{CP}$. 
This article was aimed at presenting a (re)layout proposal, developed as a strategy to implement $\mathrm{CP}$ practices in a furniture manufacturing company located in the municipality of Palhoça, in the Brazilian State of Santa Catarina, based on the analysis of production areas and sectors. Moreover, this work is part of the field research carried out by Lins et al. (2020) [28] in SMEs from the furniture industry in Southern Brazil.

\section{Literature Review}

\subsection{The Furniture Industry in Brazil and CP}

Besides being a traditional sector, the Brazilian furniture manufacturing industry includes the production of durable goods, characterized as a semi-industrial system, mainly in small enterprise production [29]. The furniture manufacturing industry has a relevant role in the wood production chain, as well as a strong social impact. In 2017, 19.6 thousand companies from the sector were responsible for generating 268.9 thousand job posts in the country, through direct and indirect employment [30]. In 2019, 18.5 thousand companies from the sector were responsible for 270.3 thousand direct and indirect jobs in the country [31], corresponding to 3.3\% of the workforce in industrial production both in 2017 and in 2019 [30,31], highlighting the importance of the sector.

In 2018, sectoral data from the furniture manufacturing industry in Brazil identified 21.8 thousand companies, with a strong presence of micro (17.3 thousand units) and small enterprises (3.8 thousand units), generating 235 thousand direct and indirect jobs [32]. Sectoral data from 2019 identified 21.2 thousand enterprises which generated approximately 232 thousand direct and indirect jobs. From 2017 to 2019, the sector experienced a reduction in direct and indirect employment, with the period of 2018 to 2019 also experiencing a decrease in the number of companies in the furniture manufacturing sector [33]. This ratifies the need for investment on research and continuous improvement projects to reduce production losses, increase the productivity and the competitiveness of the sector.

The furniture manufacturing industry is forest-based, originating from forests planted with various interconnected production links [34], manufacturing products named from solid wood (sawn) and autoclaved products, processed in the form of reconstituted wood and laminated plywood panels [32,35]. Under the Brazilian National Classification of Economic Activities (CNAE, in Portuguese), the sector is characterized as a transformation industry, being classified, according to the raw material used, as the manufacturing of furniture made of wood, metal, other materials and manufacturing of mattresses [36]. In addition, the production of upholsteries involves the use of materials such as wood, foam, synthetic fiber and fabric [29].

Figure 1 shows the connections and basic flows from the RMs to the distribution channels of the furniture manufacturing chain, in the columns denominated (a) raw materials, (b) suppliers, (c) furniture manufacturing companies and (d) distribution. The red arrows represent basic production connections (macroflows), while the blue arrows illustrate the distribution. Energy, water, supplies, the machinery and equipment industries represent the support infrastructure for all process needs, supplying all systems and being represented in the first column (a) and in the beginning of each one (b)-(d) by red dash-colon lines. The byproducts and production losses are located in the base of all systems and were represented by green arrows, as shown in the legend in Figure 1. 


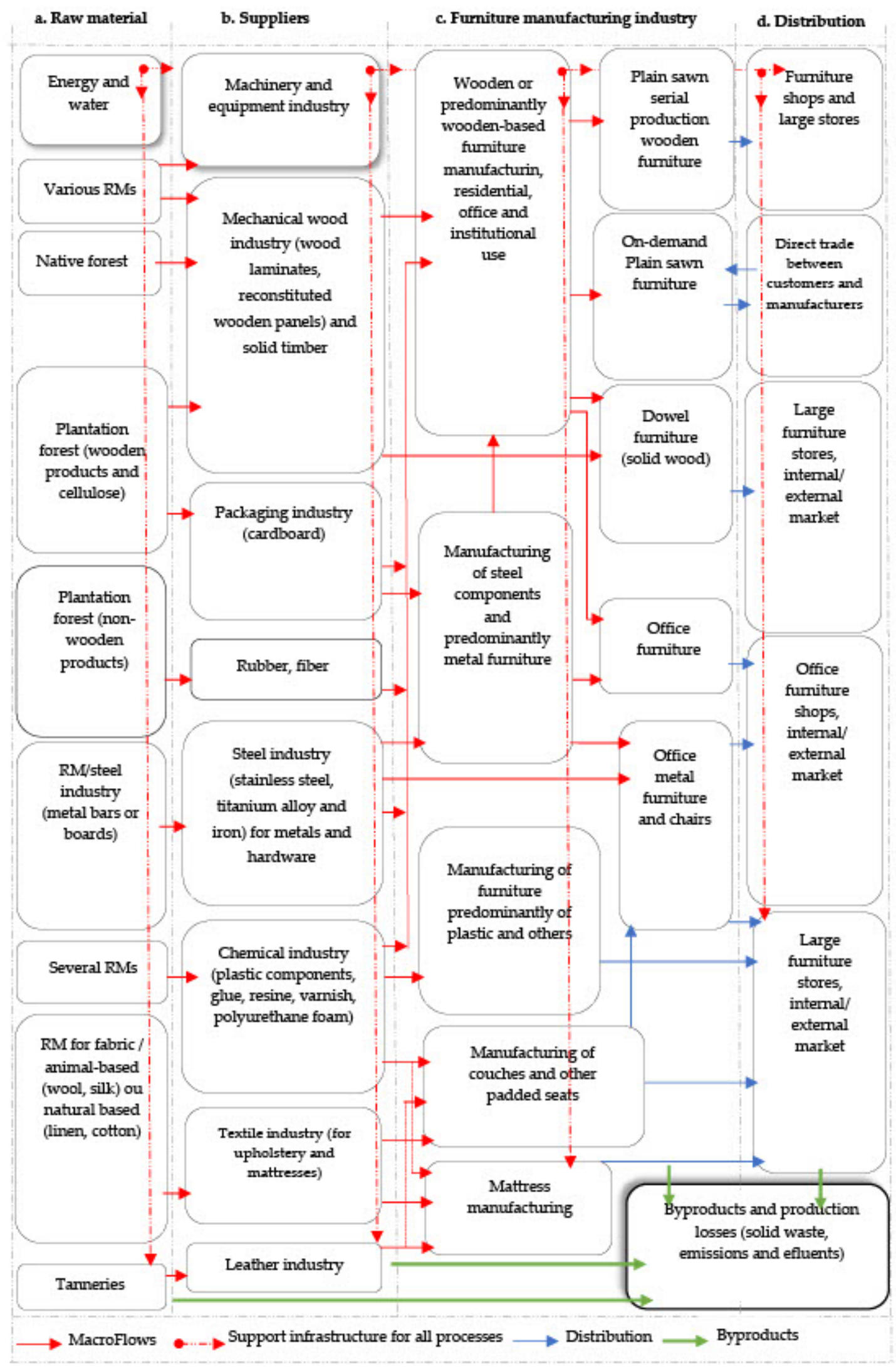

Figure 1. Production chain of the furniture industry. Created by Lins (corresponding author).

In the same figure, column (a) shows that the RMs of the furniture manufacturing industry also originate from natural and plantation forests, from the extraction of nonwooden 
products such as rubber and natural fiber (wicker, straw, rattan, bamboo, coconut shells) used in the structure, accessories and coating of products. Besides, RMs also originate from the steel bars or boards produced from the steel industry (basic industry); from the chemical product industry; from the fiber (linen, cotton, jute, ramie) and leather industries for the production of fabric and coatings for upholstery and mattresses.

The furniture industry relies on suppliers of machines and equipment, as well as on the steel industry for manufacturing steel profiles, hardware, components, accessories, as well as on the textile, chemical and the mechanical wood industries for processing wood laminates, reconstituted wood panels (plywood, fiber, medium-density fiberboardMDF, medium-density particleboards-MDP, oriented strand boards-OSB, high-density fiberboard-HDF), besides solid timber and wooden dowels [33] (Figure 1,column b).

Predominantly wood-based furniture can be classified according to its form as either plain sawn and straight (using reconstituted wood panels) furniture as well as either curved or turned (made in lathe machine and using solid wood). Depending on its use, it can be either characterized as residential, institutional or office furniture [33] (Figure 1, column c).

Regarding the type of manufacturing process, furniture can be manufactured in batches or in serial production from models, modularization, standardization of measurements in physical and/or virtual industrial catalogues in customized and specialized furniture industry. Moreover, it can be manufactured on-demand and customized for individual projects to meet the needs of customers and of the location. The planned furniture industrial sector leads the Brazilian market with the introduction of technological and design innovations in other segments of the sector [37].

As for the distribution channels (Figure 1, column d), the products in the furniture manufacturing industry are commercialized in the internal market through a chain of retail shops specialized in residential or office furniture, large stores or supplied directly from the furniture maker to the final customer.

Metal-based, timber, curved and turned furniture are also commercialized in the external market, especially those produced from solid wood/timber, which can reach the public with a greater purchase power [33]. There is direct negotiation and trade between customers and furniture makers, namely for customized plain sawn and straight furniture, which can also be manufactured on-demand.

Studies on greenhouse emissions in the furniture manufacturing process, from obtaining Raw Materials (RM) until the final manufacturing in the factory, highlighted the use and need for transporting RMs from wood, steel, plastic, chemical, textile and packaging industries located across various regions. These transportation flows lead to environmental impacts related to the generation of waste, by greenhouse gas emissions with the transport of RMs and components, by the use of non-renewable energy [38].

The literature points out that the entire furniture manufacturing chain generates production losses, besides internal and external drawbacks to the implementation of $\mathrm{CP}$ practices. The furniture manufacturing processes generate several types of waste, namely, solid waste, emissions and effluents. If uncontrolled, the generation, emission and disposal of this waste may lead to greater environmental damage [39]. In turn, plantation forest waste may be used as renewable wood products [35]. Therefore, these production losses (waste) should be avoided, reduced or minimized by optimizing manufacturing processes. This optimization can be applied to the production system and reverted as RMs for the production of byproducts (terminology adopted in this study to refer to the waste of materials which can be used for manufacturing other products).

The internal difficulties for implementing CP in SMEs are a result of economic aspects (lack of financial resources), besides managerial, organizational, educational and technical issues (lack of clean technologies and outdated infrastructure, machine and equipment, besides the lack of specialized staff and technical know-how of $C P$ ) $[8,40,41]$. For the purpose of this study, the technical difficulties faced by the lack of adequate infrastructure [41] are considered as the internal physical infrastructure, i.e., the layout. 
Companies are responsible for generating production losses, ranging from the collection to the final disposal. There is the need to reduce the generation of production losses through better technological and organizational practices [42]. However, the legislation in force hampers the implementation of CP. Regulations should be considered as opportunities for improvement, not only for setting out legal obligations [39]. In Brazil, there are no legal norms laying down requirements for companies to implement $\mathrm{CP}$ to reduce the consumption of natural resources and the environmental impact, or even to promote the use of renewable energies and greater environmental responsibility $[8,22]$.

Studies in the furniture manufacturing sector in the Brazilian State of Rio Grande do Sul (RS) concluded that despite complying with legal requirements, companies considered the environmental legislation in place a negative aspect, prioritizing investments on productivity and cost reduction, but not ensuring the adequate disposal of materials. These companies have reduced energy consumption by implementing structural changes to the building (translucid roof tiles, tilting windows) though without adopting changes in the energy base. In addition, $70 \%$ of these firms did not take part in any environmental project, $40 \%$ having no advisory team nor a sustainable business model, while $20 \%$ promoted green marketing [43]. It is of utmost importance that companies change their position regarding production losses, optimizing RM supplies, ensuring their reuse as a valuable by-product of the production system, with an important environmental added value.

Companies are often resistant to adopting new management tools, regularly as a result of technical and financial limitations to implement environmental management actions and $\mathrm{CP}$ practices. These include organizational difficulties related to business management and the control of environmental impacts, besides the resistance from furniture makers to adopt $\mathrm{CP}$ and to cleaning production areas, as well as the lack of personnel and misplaced roles [26]. Small companies highlight the challenging aspects of their organizational structure, with limited personnel and responsibilities centered on the owner. However, the implementation of EMS, based on CP practices, in a furniture manufacturing company in Cariacica in the Brazilian State of Espírito Santo demonstrated the importance of the process for optimizing the use and reduction of MDF waste [23].

Analyses on the organizational and environmental aspects of the production of couches in the Brazilian city of Maceió revealed that one of the limitations to optimize inputs, RMs and byproducts to eliminate production losses in the generating source was the lack of interaction between staff members involved in the process, from the project until the production [29]. Economic barriers hamper the implementation of CP in SMEs in the furniture manufacturing sector, especially throughout Latin America. Nevertheless, the application of $\mathrm{CP}$ enables continuous improvement, sustainable business strategies with low complexity parameters and small financial investment [22,44].

Furniture manufacturing companies consider the segregation of byproducts unfeasible, which restricts their reuse, because the chemical products and glues used in the coat-ed panels, when mixed with solid wood, contaminate all material. However, these materials represent a high economic asset [24], which should be used to supply the stock of RMs. These materials should not be wasted, with the adoption of waste prevention and reuse strategies being important to change the companies' attitudes towards these products.

The lack of financial resources to implement $\mathrm{CP}$ can be overcome with routine actions, capable of generating economic and environmental benefits through the gradual reduction in the generation of byproducts and good rates of return on investments which are feasible for Brazilian SMEs [41]. The reduction and control of pollution in the generating source of companies in the furniture manufacturing sector can be reached through the implementation of $\mathrm{CP}$, through changes in the layout, in the operating conditions and handling of materials, as well as with technology transfer [29].

Good housekeeping practices ensure economic and environmental gains without the need for great investments. These measures to aim at minimizing or modifying processes, improving the internal organization, promoting the rational use of RMs, equipment [18] and energy. In this regard, reduction of costs, the generation of sawdust and MDF waste, 
as well the environmental impact associated to greater productivity levels are included within the overall objectives of (re)layout projects.

Studies carried out in furniture manufacturing industries in the Brazilian State of Goiás (GO) observed that the most common techniques used to develop cleaner processes included improvements in the in-house production space ( $49 \%$ of responses) and the implementation of CP (14\%) [45]. Other works concluded that the application of CP management methodology in small companies, with the analysis of flows as a step, help overcoming of internal barriers and actions to reduce the generation of productive losses [46], besides facilitating the organization of areas and sectors to optimize processes and the industrial layout, thus leading to greater productivity levels [28].

The criteria for the implementation of $\mathrm{CP}$ strategies are related to the organization, staff training, systems and technologies, and feedback assessment. The following attributes are included within the criterion systems and technologies: tools and technologies, as well as the improvement of production processes, the analysis of supply chains and Life Cycle Assessment (LCA) of products [47]. These criteria and attributes were correlated by Lins et al. (2020) [28] to the diagnostic analysis of the layout and the processes flows, establishing a new theoretical link. The authors point out that (re)layouts projects can be used as a strategy for the implementation of CP [28].

$\mathrm{CP}$ is related to Green Supply Chain Management (GSCM), used to improve operational and financial performance, as well as to improve and reduce environmental waste. According to the literature, CP strategies represent $58 \%$ of the practices for GSCM, followed by ecodesign and reverse logistics practices (55\%), and green procurement (53\%) [48]. In turn, studies on Green Furniture Manufacturing (GFM) emphasize the development of ecological products and manufacturing processes, besides an optimization of the industrial structure [49].

For the Brazilian National Center of Clean Technologies (CNTL, in Portuguese), CP implementation programs should be carried out under 5 different steps: (1) managerial commitment and identification of barriers (scope and training on ecotime), (2) flowchart and diagnosis of environmental processes (focus of the assessment), (3) material balance, indicators and identification of the source of waste generation (CP options), (4) technical, economic and environmental assessment (viability of the options), and (5) implementation and monitoring plan (continuity) [17].

Legal and environmental aspects, as well as the raw material procurement flow to supply the production chain, besides information and people flows, the flow of RMs in the physical industrial spaces and the physical industrial infrastructure, influence the productive and environmental performance, being of fundamental importance for $\mathrm{CP}$ implementation. A layout project integrated to $\mathrm{CP}$ practices materializes ecological production processes in the physical industrial space, enabling the physical integration of the design, materials, processes, reuse and recycling.

\section{2. (Re)layout Projects as a Strategy to Implement CP in the Furniture Manufacturing Industry}

The layout design process aims at systematically optimizing industrial facilities and factors that contribute to the optimization of new or existing physical spaces, focusing on the integration and harmonization of all production items [50,51]. Furthermore, it has the goal of arranging and combining departments to benefit users from the production system [52]. The layout characteristics reflect and are determined by the operations or production activities carried out in the physical space [16].

The industrial layout directly influences the performance of the production system and the results of the organization, promoting differentiation and competitive advantage $[53,54]$. The layout project analyzes risks, the value of the material to be moved and restrictive, objective, as well as subjective aspects of the physical production space [53]. The production flows are represented and influenced by how the layout is structured. Natural factors (light, heat, humidity), risk factors (physical, mechanical, chemical, biological and ergonomic), as 
well as environmental aspects are pre-requirements for projects focusing on new layouts or (re)layout projects, influencing work safety conditions.

The implementation of a (re)layout project promotes the redesign of production factors, repositions transformation resources, improves production processes, services, as well as operational management. It also has a positive influence on the enhancement and optimization of distances travelled, the flow of materials and stock, reducing displacement times and operating costs $[55,56]$.

Studies applied to the furniture manufacturing industry demonstrate that integrating $\mathrm{CP}$ to a (re)layout project is a strategic and innovative action which aims at removing and/or minimizing the waste of the flow of materials, people and production, allowing one to reuse materials and improve the performance of the production system and of the areas in the production centers. The "integration of CP in the process flow analysis of layout projects provides greater opportunity for reducing waste at the generating source, reducing the small company's environmental impact, considering the existing systems and technologies" [28] (p. 20).

At an international level, research on the assessment of the wood recovery protocol at two wood manufacturing industries in Indonesia concluded that the recovery in furniture SMEs runs into economic barriers, which hinder greater production efficiency. Moreover, the layout influences the production capacity, being considered one of the factors related to higher costs and lower wood recovery rates. The total wood recovery rate was of $29.6 \%$ in one industry and of $23.7 \%$ in another [57]. The same study showed that methods to assess the physical layout and the production systems are important to allow the identification of critical points and opportunities to recover materials for reuse.

In the furniture manufacturing industry in Turkey, the simultaneous simulation, layout redesign and the reorganization of departments in SMEs (involved in the manufacturing of wooden chairs) led to the development of an integrated method for greater work performance [58]. The research demonstrated the importance of adopting integrated and systemic approaches that can be used to associate (re)layout to CP and information flows.

In Brazil, the analysis of process flows in an office furniture manufacturing industry located in the Brazilian municipality of Palhoça (SC) identified a total of $775.58 \mathrm{~m}$ of flow lines, with $66.93 \mathrm{~m}$ representing returns and crossings. Moreover, the project highlighted an area of $107.24 \mathrm{~m}^{2}$ wasted, with $72.06 \mathrm{~m}^{2}$ of the floor area occupied with materials to be discarded as production losses. The (re)layout project allowed to rationalize the production space, pointing out 25 opportunities of CP by optimizing systems and technologies, reducing production waste in areas and flows, internal rearrangements considering the proximity of inter-related sectors [28].

Studies in furniture manufacturing industries in the Brazilian State of Minas Gerais (MG) highlighted that the layout redesign, besides the rearrangement of the workspace and production areas reduced costs, enabled greater efficiency levels, greater productivity and production capacity $[59,60]$. Changes in the process, the position of machines and sectors ensured a better use of areas, of the demarcation of movement and safety areas, leaving aisles unobstructed, ensuring time and movement reductions, besides improvements to safety with the removal of risks at work [60].

Studies carried out in three furniture manufacturers in the Brazilian municipalities of Alegre and Jerônimo Monteiro, in the State of Espírito Santo (ES), analyzed the layout, the position of machines, the ergonomic conditions and flows. The proposals optimized ergonomic factors, production flows, comfort and safety conditions of the workspaces, increasing productivity. The repositioning of the machines in the layout enabled the optimization of effective working time, with the reduction of dispersed works [61].

Changes in the layout have a technological purpose, focused on the reductions of waste at the source $[17,18]$. In addition, they are also related to competitive priorities and to production capacity, as well as to the introduction of technological innovations and/or the manufacturing of new products. They also facilitate communication, information flows, besides the flow of people and materials, promoting enhancements to the position and 
optimization of the use of areas and processes, reducing costs, production time and losses, thus increasing productivity and safety in the work environment $[16,54,60,62]$.

The factors which influence layout projects include external or internal changes, services (internal or external benefits offered to customers and personnel), labor work, materials (quantity and features), waiting time (delays and stocks), equipment, building (structural aspects) and the movement of materials and personnel [50,52]. These factors are related to the criteria and attributes for the implementation of $\mathrm{CP}$ practices, especially to the criterion of systems and technologies [46,47].

The movement factor refers to the displacement of materials and personnel throughout the manufacturing process, as well as to the flow of the production processes. The diagnosis highlights the fluidity of flows, floor obstruction, distances travelled, returns, crossings, risks, value and inter-relations between the areas and sectors $[50,52,53]$. The factor waiting time regards the storage and stock areas, located in the center of the production areas, waiting for the subsequent movement [50,52].

The methodology applied in the layout project is divided into three steps: (1) general layout (design of areas and flows between departments), (2) detailed layout (design of the spatial needs for machines, equipment, operations, personnel, accesses, transport, and the sequence of operations between the workstations) and (3) adjustments to the general layout (redesign of areas). Under this methodology, the factors that influence the layout are applied to the three steps. The areas for design of the project can be subdivided into work centers, circulation, office, sanitary facilities, dressing rooms, food court and kitchen. For the design of flows, it is necessary to define the production, auxiliary and service departments, besides the sequence of production and administrative activities, as well as the analysis of the type of material and flow between departments [50-52].

In sum, (re)layout projects are defined as a strategy for the implementation of CP practices in small businesses, taking into account the inter-relation between their objectives for the optimization of spaces which encompass the production processes, contributing to increasing levels socio-environmental responsibility, as well as the productive adaption and flexibility to new scenarios in the furniture manufacturing industry.

\section{Materials and Methods}

This work is characterized as applied research, following a multi-methodology: literature review and case study. The case study was carried out in a micro company located in the municipality of Palhoça, in the metropolitan area of the Brazilian city of Florianópolis (SC), which produced 10 office furniture lines (call center, workstations, platforms, reception, drawers, shelves, desks and archives).

Step A was the first presential encounter for field studies and technical visits. In this step, carried out in 2015, authors Lins and Merino collected data through two technical visits aimed at mapping areas and sectors (company's features and characteristics of its physical layout) and production monitoring. Subsequently, 3 non-presential steps were performed: Step B (for description and integrated analyses), C (for identifying critical points and $\mathrm{CP}$ opportunities) [28] and $\mathrm{D}$ (for generating project alternatives, assessment and choice), which served as the basis for the present article (Figure 2).

The two technical visits (Step A) were preceded by planning, project and literature review. The first technical visit involved the application of an integrated checklist (CP and layout) and photographic surveying. The second technical visit, was to measurements of the base layout for carrying out the research and project, as well as the monitoring of the production process and respective photographic survey.

The conceptual - theoretical literature review concentrated on the keywords: layout, (re)layout, "physical arrangement", "Cleaner Production" (CP), "furniture manufacturing industry" (in Portuguese and in English). The literature review was carried out in books and in the Capes, Scopus and ScienceDirect databases. 


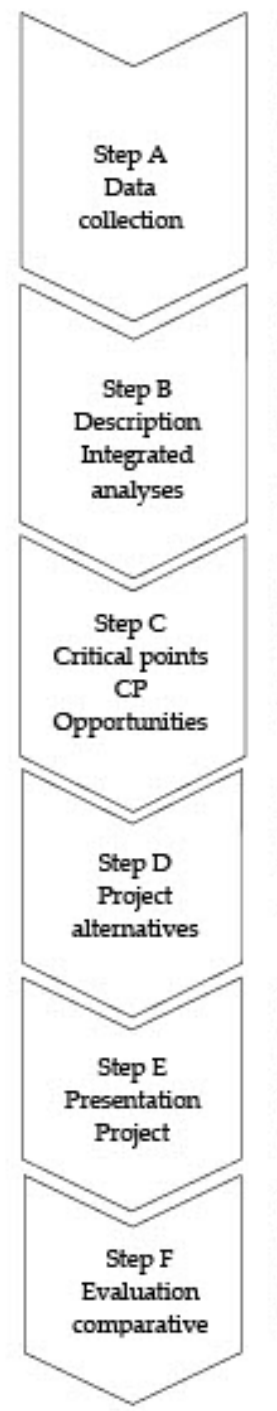

1. Technical visit 1 for data collection (layout and CP).

1.1. Agreement and authorizations from the company.

1.2. Mapping of the location, its surroundings and internal area of the company.

1.3. Integrated Checklist application (layout and CP).

1.4. General photographic survey (areas and sectors).

2. Technical visit 2 for collecting metric data and monitoring production.

2.1. Building and layout measurements (position of machines, equipment, fumiture, materials).

2.2. Monitoring production (flows of processes, people and materials) and photographic survey of the production process.

1. Description of data and processes for integrated analytics.

2. Floor plan drawing of industrial facilities and layout (areas and sectors).

3. Floor plan drawing of detailed layout, with the position of machines, equipment, furniture and materials.

4. Development of a Manufacturing and Assembly Flowchart (MAF) to describe activities and their interrelationships.

5. Floor plan with the zoning of areas in the layout for the analysis of areas integrated to $C P$.

6. Floor plan with the design of flow lines in the layout integrated to the MAF for analyses.

7. Diagnostic analyses integrated to processes, areas, sectors, flows and production losses.

1. Identification of critical points: losses related to areas, sectors, flows and environmental losses.

2. Identification of CP opportunities from the layout analyses associated to the implementation of $\mathrm{CP}$.

3. Drafting techrical reports on the data collected.

4. Measurement of parameters in the base layout ( $\%$ of use of areas, discharge of materials and production waste, $\%$

of flow lines) to support the analysis and choice of project alternatives and the comparative analysis.

1. Generating alternatives to (re)layout project integrated to $\mathrm{CP}$ practices.

2. Comparative analysis, assessment and choice of alternatives of the (re)layout project.

3. Development of the (re)layout project integrated to CP.

4. Drafting document for presenting the (re)layout project integrated with $\mathrm{CP}$ for the company.

1. Technical visit 3 for presenting the results of the research and of the (re)layout project integrated to $\mathrm{CP}$.

1.1. Presentation, discussion and delivery (layout project integrated to CP)

1.2. Updates to the data collected and new measurements.

1.3. New photographic survey for comparation.

1.4. Confirmation of analyses and $C P$ opportunities.

1. Analysis of base layout and (re)layout project (areas and sectors as a measurement parameter).

2. First results of the research published in 2020 [46]

3. Comparison of the parameters ( $\%$ of use).

4. Finalize the (re)layout project for the implementation of $\mathrm{CP}$ from the analysis of production areas and sectors.

5. Drafting reports and techrical documents for publishing results.

Figure 2. Steps for carrying out the present research. (Re)layout project integrated CP.

Step B (non-presential) consisted of the description, technical design, development of analysis tools which culminated in the identification of Critical Points on the associated base layout for the implementation of CP (Step C, non-presential). The criteria and attributes for the implementation of CP [47] and layout project factors [50,52] were interconnected and formed the theoretical framework for the diagnostic analyses of areas, sectors and flows, thus contributing for the identification of CP opportunities associated to the flow of processes and analysis of areas and sectors (Step C) (Figure 2).

In Step D (non-presential), the planning, project and literature review are concentrated on the drafting, choice and assessment of alternatives of (re)layout projects and implementation of CP. It also involved the methodology for drafting the industrial facilities project and layout design [50-52] and CP implementation [17,18].

Step E corresponded to the second presential moment for field studies and technical visits. It was carried out in 2018 and had the participation of authors Lins and Rapôso. It was preceded by the design and work plan to ensure the feasibility of a technical visit for the presentation and delivery of the project to the case study company to update the data for the diagnostic analyses and CP opportunities, besides the assessment of the project for subsequent adjustments (Figure 2).

Step $\mathrm{F}$ assessed the project, and carried out the adjustments and comparative analyses of the measurement parameters (in percentage terms of area usage), maintaining the contact of the company in a non-presential manner to follow-up (Figure 2). Figure 2 details 
and summarizes the steps for carrying out the present research, and it can be used in future works, especially those focused on small companies in the furniture manufacturing industry. The research steps represent the methodological contribution for carrying out projects aimed at the non-generation and/or minimization of production loses in the industrial production space.

\section{Results and Analyses}

\subsection{Diagnostic Analysis of the Case Study Company}

This research was carried out in a Micro Company (MC) of office furniture manufacturing and trade, set out in an area of $1410 \mathrm{~m}^{2}$ in a commercial and industrial space in the Brazilian city of Palhoça (SC). According to the Brazilian Micro and Small Business Support Service (SEBRAE), a Micro Enterprise (ME) is a small business with a turnover equal to or less than BRL 360k, with up to 19 employees (Law n 123/2006) [63,64].

Data from the Brazilian furniture manufacturing industry from the years of 2017, 2018 and 2019 corroborate this choice. In 2017, there were 21.8k furniture manufacturing companies in the country, with $86.1 \%(18,220$ thousand) producing predominantly woodbased furniture [32,33], concentrated along the South and Southeast regions of Brazil. In 2018, 17.3k units were Micro Enterprises (ME). In turn, in 2019, this amount reduced to 16.8k units [32,33]. In 2019, 437.5 million furniture units [31,33] were produced, with most representing bedroom furniture (33.2\%), followed by office furniture (17.3\%) [31].

Figure 3 presents the furniture manufacturing process and the Synthetic Flow Chart of Manufacturing and Assembly (SFCMA). The SFCMA is the synthetic representation of the manufacturing and assembly process, defining the activities necessary for the productions, as well as the order of these activities and the definition of material flows throughout this process [15,16,50-52]. The SFCMA of the company was developed based on the technical visits carried out in 2015 and 2018 for data collection and monitoring of the production, consisting of the description of the diagnostic analyses (Steps A and B of the research). The production was divided into processes for manufacturing tabletops, straight and curved connection components (process A), manufacturing cupboards, shelves and partitions (process B) and manufacturing of drawers (process C). In 2015, the company's organigram took account of one director and 17 employees (receptionist, manager, production supervisor, carpenters and assistants). The company was subdivided into the Planning and Production Control (PCP) sectors, with the production supervisory being concentrated in the administrative section due to lack of space in the production area.

In the production area, the employees (carpenters and assistants) were distributed along the following sectors: cutting of furniture components (processes A, B and C, 1st line of Figure 3), processing (processes A and B, 3rd row), automatic and/or manual gluing of edges (processes A, B and C, 6th row), drill and pre-assembly/assembly (processes A, B and $C, 9$ th row), packaging/accessory selection/dispatch (processes A, B and C, 12th row).

The first column of Figure 3 shows the inflow of machines, equipment, supplies, RMs and other materials necessary for manufacturing the furniture components. The second, third and fourth columns depict the sequence of processes $\mathrm{A}, \mathrm{B}$ and $\mathrm{C}$, identifying displacements (rows 2, 5, 8, 10, 13 of the SFCMA), intermediary stock of components being processed (rows 4 and 7 of the SFCMA) and finished material (11th row).

The last column outlines the outputs of the system, i.e., products, production waste (waiting time, delays, distances traveled, intermediary stocks, critical points and floor obstruction), as well as environmental waste (sawdust, wood shavings and MDF/MDP waste, nylon tapes, cutting disks, MDF + Glue + Edging Tapes (ET), tabletops /ET, tows, solvents, packaging, plastic, carboard, adhesive tape, gases/combustion). The data collection did not allow us to establish the mass balance due to the limited time available for data collection (step A, presential). 


\begin{tabular}{|c|c|c|c|c|}
\hline \multicolumn{5}{|c|}{ Synthetic Flow Chart of Manufacturing and Assembly (SFCMA) (inputs, processes and outputs) } \\
\hline $\begin{array}{l}\text { Inputs } \\
\text { Machines/equipment and } \\
\text { supplies } \\
\text { Raw Materials (RM) and } \\
\text { other materials }\end{array}$ & $\begin{array}{l}\text { A) } \\
\text { Manufacturing of } \\
\text { tabletops, } \\
\text { straight and } \\
\text { curve connection } \\
\text { components } \\
\end{array}$ & $\begin{array}{l}\text { B) } \\
\text { Manufacturing of } \\
\text { cabinets, shelves } \\
\text { and } \\
\text { partitions }\end{array}$ & $\begin{array}{l}\text { C)Manufacturing } \\
\text { of } \\
\text { drawers }\end{array}$ & $\begin{array}{l}\text { Outputs } \\
\text { Products } \\
\text { Waste } \\
\text { Environmental } \\
\text { waste }\end{array}$ \\
\hline $\begin{array}{l}\text { 1st Machines/Equipment } \\
\text { Electrical energy } \\
\text { Device gauge } \\
\text { MDF/MDP } \\
\text { Cutting disk }\end{array}$ & $\begin{array}{l}\text { MDF/MDP } \\
\text { Component cutting }\end{array}$ & $\begin{array}{l}\text { MDF/MDP } \\
\text { Component cutting }\end{array}$ & $\begin{array}{l}\text { MDF/MDP } \\
\text { Component cutting }\end{array}$ & $\begin{array}{l}\text { Cut MDF/MDP } \\
\text { components } \\
\text { Energy } \\
\text { Sawdust, wood } \\
\text { shavings, MDF waste, } \\
\text { nylon tapes, cutting } \\
\text { disks }\end{array}$ \\
\hline $\begin{array}{l}\text { 2nd } \\
\text { Equipment/Transportation }\end{array}$ & & & & Distanceftime \\
\hline $\begin{array}{l}\text { 3rd Machines/Equipment } \\
\text { Electrical energy } \\
\text { Device gauge } \\
\text { MDF/MDP }\end{array}$ & $\begin{array}{l}\text { MDF/MDP } \\
\text { processing }\end{array}$ & $\begin{array}{l}\text { MDF/MDP } \\
\text { processing }\end{array}$ & & $\begin{array}{l}\text { Processed MDF/MDP } \\
\text { Energy } \\
\text { Sawdust, wood } \\
\text { shavings, MDF waste, } \\
\text { nylon tapes }\end{array}$ \\
\hline 4th stock for processing & & & & $\begin{array}{l}\text { Time (delays), floor } \\
\text { obstruction }\end{array}$ \\
\hline 5th Equipment/transportation & & & $\zeta$ & Distanceftime \\
\hline $\begin{array}{l}\text { 6th Machines/Equipment } \\
\text { Electric Energy } \\
\text { Cut and manufactured } \\
\text { MDF/MDP, edge tape, glue, tow } \\
\text { and solvent }\end{array}$ & $\begin{array}{l}\text { Automatic and } \\
\text { manual edge gluing }\end{array}$ & $\begin{array}{l}\text { Automatic edge } \\
\text { gluing }\end{array}$ & $\begin{array}{l}\text { Automatic } \\
\text { gluing }\end{array}$ & $\begin{array}{l}\text { Taped MDF/MDP } \\
\text { Energy } \\
\text { MDF+Glue+Edging } \\
\text { Tape (ET), top/ET, } \\
\text { tows, solvents. } \\
\text { packaging }\end{array}$ \\
\hline 7th stock for assembly & & & & $\begin{array}{l}\text { Time/delay and floor } \\
\text { obstruction }\end{array}$ \\
\hline $\begin{array}{l}\text { 8th } \\
\text { Equipment/transportation }\end{array}$ & & & & Distance/time \\
\hline $\begin{array}{l}\text { 9th Machinery/equipment } \\
\text { Electrical Energy } \\
\text { Drill gauge } \\
\text { Taped MDF/MDP. Accessories }\end{array}$ & $\begin{array}{l}\text { Drill and pre- } \\
\text { assembly? }\end{array}$ & $\begin{array}{l}\text { Drill and } \\
\text { assembly }\end{array}$ & Drill and assembly & $\begin{array}{l}\text { Finalized furniture } \\
\text { Energy } \\
\text { Packaging, plastic, } \\
\text { cardboard, sawdust } \\
\end{array}$ \\
\hline $\begin{array}{l}\text { 10th } \\
\text { Equipment/transportation }\end{array}$ & & & & Distanceftime \\
\hline 11th Finished material stock & & & & $\begin{array}{l}\text { Time (delay), floor } \\
\text { obstruction }\end{array}$ \\
\hline $\begin{array}{l}\text { 12th Finalized furniture } \\
\text { Electrical energy } \\
\text { Bubble wrap, adhesive tape, } \\
\text { cardboard, accessories }\end{array}$ & $\begin{array}{l}\text { Packagind/accessory } \\
\text { selection/dispatch }\end{array}$ & $\begin{array}{l}\text { Packaging/actessory } \\
\text { selection/dispatch }\end{array}$ & $\begin{array}{l}\text { Packaging/acbessory } \\
\text { selection/dispatch }\end{array}$ & $\begin{array}{l}\text { Packaged furniture } \\
\text { Energy } \\
\text { Bubble wrap, adhesive } \\
\text { tape, cardboard } \\
\end{array}$ \\
\hline 13th Vehicle, fuel & & & & $\begin{array}{l}\text { Distance/time } \\
\text { Gases/combustions }\end{array}$ \\
\hline $\begin{array}{l}\text { 14th Finalized/packaged } \\
\text { furniture } \\
\text { Energy } \\
\text { Portable machines } \\
\text { Pieces and accessories }\end{array}$ & $\begin{array}{l}\text { Assembly at the } \\
\text { customers' facilities }\end{array}$ & $\begin{array}{l}\text { Assembly at the } \\
\text { customers' facilities }\end{array}$ & $\begin{array}{l}\text { Assembling } \\
\text { drawers and } \\
\text { handles at the } \\
\text { customers' facilities }\end{array}$ & $\begin{array}{l}\text { Furniture delivered } \\
\text { Customer's energy } \\
\text { Packaging plastic, } \\
\text { bubble wrap, adhesive } \\
\text { tape, cardboard }\end{array}$ \\
\hline$\quad$ Process flow & Transportation & $\nabla^{\ln }$ & & $D^{\text {Time/wait/delay }}$ \\
\hline
\end{tabular}

Figure 3. Synthetic Flow Chart of Manufacturing and Assembly (SFCMA). Created by Lins (corresponding author).

The analysis showed floor areas filled with materials for disposal, besides production and environmental waste. In addition, the study revealed that intermediary stocks in-between the processes caused floor obstruction, besides waiting times and delays, hampering the dispatching stage.

The lack of synchronization of the processes and orders, the flows and floor obstructions with the intermediary stock of components and materials for disposal in the layout also caused delays in the manufacturing and in complying with the delivery deadlines. 


\subsubsection{Zoning Analysis (a.) of the Base Layout}

The zoning plan of the areas (Figure 4) presents the physical space of the company studied, considering the base layout (considered as reference for all studies). The floor plan presented in Figure 4 identifies the location of the administrative/sales area (a.1), staff support (a.2), stock/storage (a.3), production, packaging/dispatch (a.5), byproducts (a.6), circulation (a.7) and unused external area (a.8).
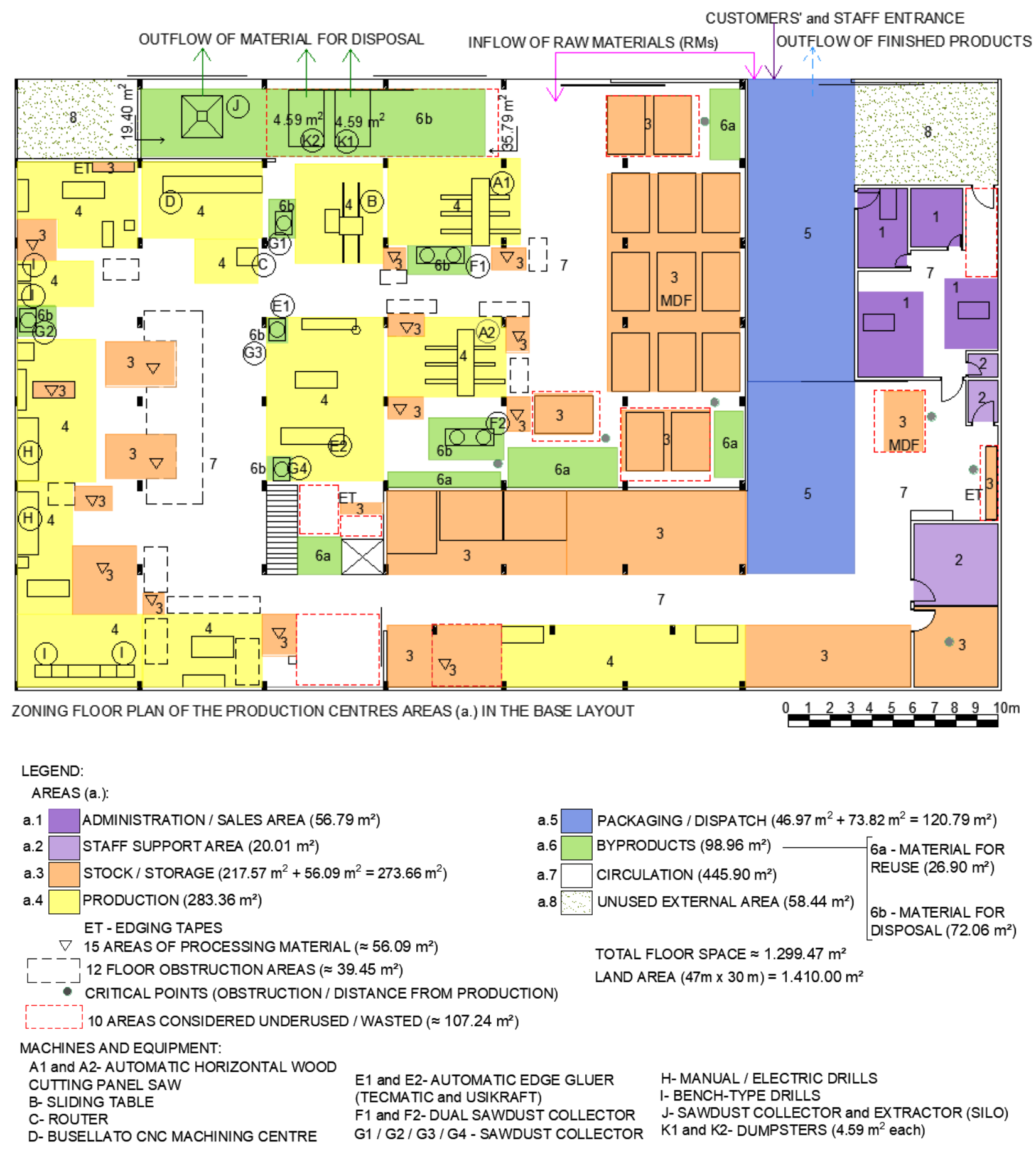

Figure 4. Zoning floor plan of the Production Centers (PCs) areas (a.) in the base layout.

Figure 4 locates the Production Centers (PCs), machines and equipment, stock of materials in use, stock of material for reuse and disposal, inflow of raw materials (pink 
arrow) and of customers (purple arrow), outflow of finished materials (blue dashed arrow), and environmental waste from disposal (green arrow).

Figure 4 identifies the location of the Production Centers (PCs), machines and equipment, stock of materials in use, stock of material for reuse and disposal, inflow of raw materials (arrow in pink) and of customers (purple arrow), outflow of finished materials (blue dashed arrow), and environmental waste from disposal (green arrow).

The floor plan in Figure 4 also outlines the fragmentation of the production areas $\left(283.36 \mathrm{~m}^{2}\right)$, stock areas $\left(273.66 \mathrm{~m}^{2}\right)$, areas for byproduct allocation $\left(98.96 \mathrm{~m}^{2}\right)$, circulation $\left(445.90 \mathrm{~m}^{2}\right)$, thus verifying that only $27.18 \%$ (area $\left.6 \mathrm{a} / 26.90 \mathrm{~m}^{2}\right)$ of the total area for byproducts $\left(98.96 \mathrm{~m}^{2}\right)$ is allocated for reuse. In addition, $78.82 \%$ of this area is wasted with the allocation of materials for disposal (area $6 \mathrm{~b} / 72.06 \mathrm{~m}^{2}$ ). Moreover, the floor plan shows a waste of $107.24 \mathrm{~m}^{2}$ in working areas (red dashed rectangle), with the byproduct areas (area 6a, outlined as critical points), located opposite the MDF stock (close to the inflow of RMs, area 3), hampering and/or preventing the access for reuse.

Following the measurements, it was possible to verify that $76.58 \%$ of the area allocated to byproducts for disposal (area $6 \mathrm{~b} / 55.19 \mathrm{~m}^{2}$ ) was occupied with the silo $\left(\mathrm{J} / 19.40 \mathrm{~m}^{2}\right)$, container (K1) for trash disposal and the dumpster (K2) for MDF/MDP waste and rubble $\left(35.79 \mathrm{~m}^{2}\right)$-all parallel to the access to facilitate collection. The MDF/MDP stocks occupied $100.00 \mathrm{~m}^{2}$ of the floor area, being located close to the access for raw materials, to the production and cutting machine areas (A1 and A2) in order to facilitate the reception of materials and transportation. Nevertheless, 1 batch of MDF and edging tapes (ET) and storage room were located next to area 2 and far away from the production area (a.4), causing unnecessary displacements (outlined as critical points).

Figure 4 highlights 12 areas of floor obstruction (approximately $39.45 \mathrm{~m}^{2}$ ), represented by black dashed rectangles, as well as 15 areas of stocks of intermediary material on-hold, for processing $\left(56.09 \mathrm{~m}^{2}\right)$, waste of prejudicial areas to the physical layout, transport, movement, storage and material handling in the $\mathrm{CPs}$, which show a lack of planning and control in terms of the movement and location of materials in the layout.

\subsubsection{Analysis of Production Centers (PCs) and Sectors (s.) in the Base Layout}

The floor plan of the Production Centers (PCs) and sectors (s.) in the base layout (Figure 5) details and locates the machines and equipment, as well as the type of stocks of materials and byproducts, extraction pipes of sawdust particles in the layout.

Figure 5 identifies the location of fire extinguishers (grey dashed circles), their spanning range (10.00 m, in accordance with NR-23) [65] and critical points with areas out of range. It also identifies 8 areas of storage room and specifies the types of stocked material. The storage room (sector 14) stocked components and accessories used in the drilling sectors (sectors 20a, 20b and 22) and assembly sectors (sectors 21, 23a and 23b).

It was also observed that the processes which generated more byproducts and environmental waste were cutting (sectors $15 \mathrm{a}, 15 \mathrm{~b}$ and 15c) and machining (s. 16), despite the MDF/MDP cutting plans carried out in the Production Planning and Control Center (PPC) (s. 4). The company also disposed of pipes, sawdust collectors for extraction and pipes directed towards the silo to avoid the dispersion of MDF/MDP particles in the air. However, the lack of proper sealing of the physical space around the extractor (silo) (s. 32) increased the dispersion of particles when emptying it, thus impregnating $249.21 \mathrm{~m}^{2}$ of floor area with MDF/MDP particles after each extraction (area affected outlined with a green dashed rectangle in green).

The supply of RMs for the stocks was carried out via 2 different access points (supply flow lines in pink), conflicting with the access of customers and the outflow of finished material (s. 25). The packaging/dispatch sector (s. 24) was located in the end of the process chain, close to the entrance/exit of trucks and to the exit of finished materials.

The position of the sectors followed the production flow sequence. Nevertheless, the analysis outlined the need for optimizing the PCs eliminating returns and crossings in order to enhance the movement of materials throughout the process (Figure 5) and 
minimize flows. The Critical Points observed in each area (a.) and sector (s.), besides the technical barriers related to the physical infrastructure and to the systems and technologies are summarized in Table 1, being considered challenges to the implementation of $\mathrm{CP}$.

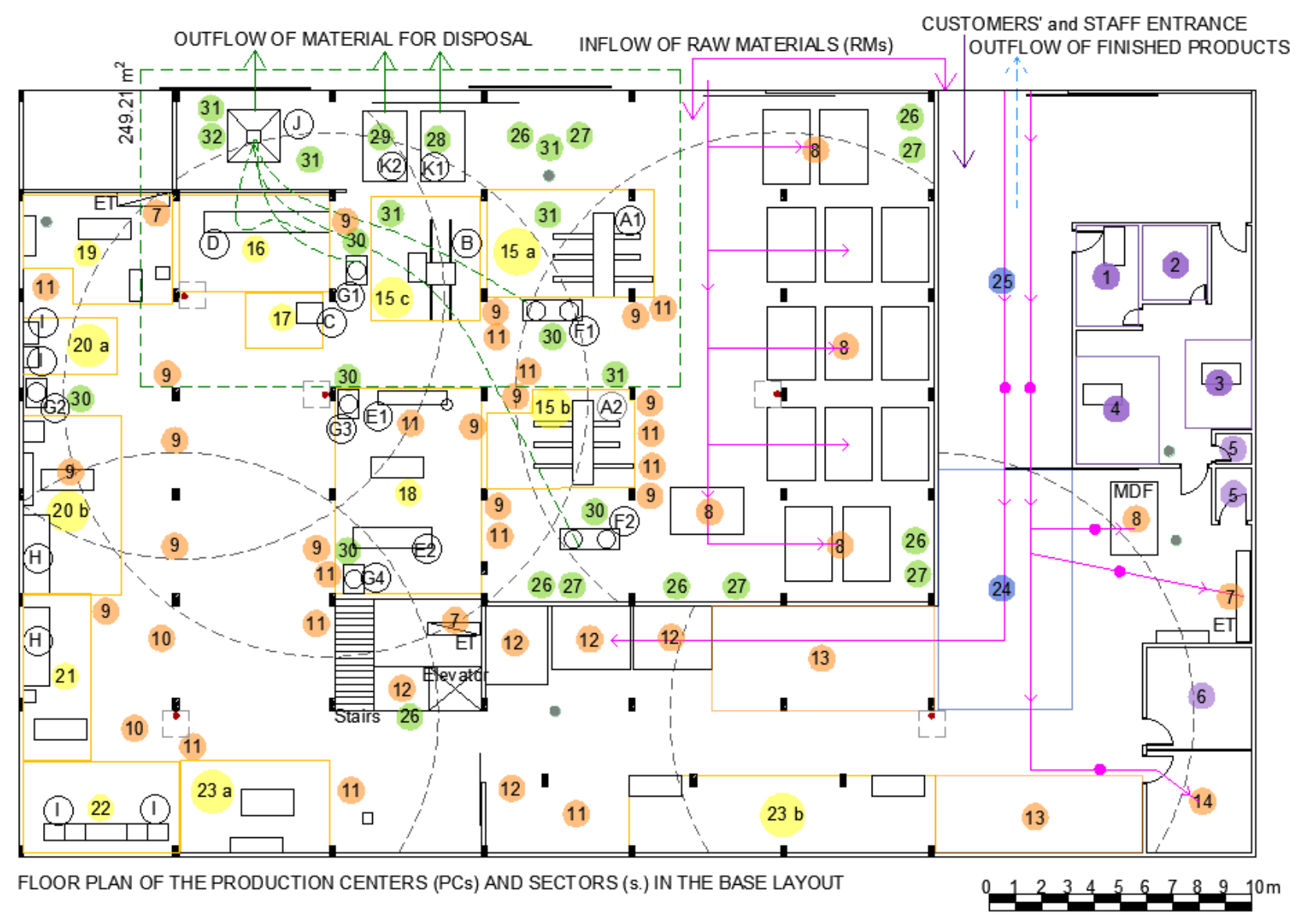

LEGEND:

SECTORS (s.):

S.1 RECEPTION S. 9 STOCK OF COMPONENTSIDRAWERS S. 17 ROUTER

s. 10 STOCK / ASSEMBLED DRAWERS

s. 18 AUTOMATIC GLUENG OF

s. 24 PACKAGING / DISPATCH

s.3 MANAGEMENT

s. 11 STOCK OF COMPONENTS FOR

EDGE TAPE (ET)

s. 25 ENTRANCE / EXIT OF TRUCKS

s. 4 OFFICE/ PPC

ASSEMBLING CUPBOARDS AND TABLES

s. 19 MANUAL GLUENG OF EDGE

s. 26 BYPRODUCTS (MDF/CARDBOAD)

s. 5 WC

s. 12 CARDBOARDS STOCK

TAPE (ET)

s. 6 KITCHEN

s. 13 STOCK OF FINISHED MATERIAL

s. 20 MANUAL DRILLING /

DRAWERS $(a, b)$

s. 7 EDGING TAPE (ET) s. 14 STORAGE ROOM

STOCK S. 15 CUTTING SECTOR $(a, b, c)$

s. 8 MDF STOCK S. 16 CNC MACHINING CENTRE

s. 21 ASSEMBLY / DRAWERS

s. 22 CUPBOARD DRILLING

s. 23 ASSEMBLY/CUPBOARDS (a, b) EXTRACTOR (SILO)

MACHINES AND EQUIPMENT:

A1 and A2- AUTOMATIC HORIZONTAL WOOD I-BENCH-TYPE DRILLS

CUTTING PANEL SAW

B- SLIDING TABLE

C- ROUTER

D- BUSELLATO CNC MACHINING CENTRE

E1 and E2- AUTOMATIC EDGE GLUER

(TECMATIC and USIKRAFT)

F1 and F2- DUAL SAWDUST COLLECTOR

G1 / G2 / G3 / G4 - SAWDUST COLLECTOR

H- MANUAL / ELECTRIC DRILLS
$\mathrm{J}$ - SAWDUST COLLECTOR and EXTRACTOR (SILO)

K1 - DUMPSTERS / TRASH (MDF/MDP

FOR DISPOSAL) $\left(4.59 \mathrm{~m}^{2}\right)$

K2 - DUMPSTERS / TRASH

(N/MATERIALS FOR DISPOSAL) $\left(4.59 \mathrm{~m}^{2}\right)$ AREAS OF PRODUCTION CENTRES

$--\neg$ AREA WITH SAWDUST PARTICLES ON L $\perp$ THE FLOOR AND MACHINES $\left(249.21 \mathrm{~m}^{2}\right)$
- FIRE EXTINGUISHERS (A, B, C)

CRITICAL POINTS OUT OF THE RANGE OF FRE EXTINGUISHERS

COVERAGE RADIUS OF FRE EXTINGUISHERS $\rightarrow(10.00 \mathrm{~m})$

- - EXTRACTION PIPES OF SAWDUST PARTICLES (SUSPENDED)

$\longrightarrow$ SUPPLY FLOW LINES (86.96 m)

- CRITICAL SUPPLY LINES (CRITICAL POINTS)

Figure 5. Floor plan of the Production Centers (PCs) and sectors (s.) in the base layout. 
Table 1. Critical Points in the physical infrastructure, systems and technologies per area (a.) and sector (s.).

Areas (a.) Types and Number of Critical Points in the Physical Infrastructure, Systems and Technologies, in the Layout
and on the CP Layout per Area (a.) and Sector (s.)

(1) Conflict between the area allocated to the entrance of customers for reception (sector 1 or s. 1) and the exit of vehicles from the dispatch sector (s. 25) for delivery; (2) Location of the Production Planning and Control Center (PPC) (s. 4) in the administrative area (area 1 or a.1) far from the production area (a.4); (3) Difficulty in controlling the cutting processes (sectors 15a, 15b and 15c), machining center (s.16) and router (s.17), automatic (s.18) and

a.1 manual (s.19) edge taping from the PPC (s.4) due to the distances needed to carry out the work; (4) Environmental actions restricted to the collection of MDF/MDP components in dumpsters (K1 and K2) and sawdust in the silo (J) for disposal by specialized company; (5) Costs with the removal of production waste for disposal of materials; (6) Absence of company participation in projects related to the minimization of resource waste, environmental management, CP or ecodesign; (7) Delays in the delivery.

(1) Lack of space for the interaction between the team and training; (2) Lack of rest area, locker room and bathrooms separated per gender; (3) Lack of training related to environmental waste.

(1) Fragmentation of stock/storage areas (a.3); (2) Critical supply lines facing difficulties in transporting a batch of edging tapes (s.7) and MDF (s.8) to taping (sectors 18 and 19) and cutting sectors (sectors 15a, 15b and 15c), stocked close to the kitchen (critical points of supply in pink, Figure 5); (3) Distance to storage room (s. 14) for the drilling sectors (sectors 20a, 20b and 22) and assembly (sectors 21, 23a and 23b), hampering the transportation of components and accessories; (4) Fragmented storage of byproducts in the production area (a.4); (5) Materials standing on pillars, walls and machines hampering the organization of the physical space, the movement and control of production.

(1) Old machines without an energy efficiency seal; (2) Lack of cleaning routine procedures of machines and physical space; (3) Lack of sealing of the space surrounding the silo; (4) Portable machines on benches and scattered around the centers, without a designated and suitable storage space; (5) Obstruction of equipment for fire extinguishing close to the drilling sectors (s.22) and cupboard assembly (sectors 23a and 23b); (6) Returns and crossings of flows for processing materials between the machining (s.16), router (s.17), automatic and manual taping

a.4 (s.18) sectors; (7) Floor obstruction in production (a.4) and circulation (a.7) areas with materials in processing and byproducts; (8) Restrictions in the supply of the manual drilling sector of drawers and cupboards (sectors 20a, 20b and 22), as well as the assembly of drawers and cupboards (sectors 21, 23a and 23b) due to the distance from the storage room (s. 14); Separation of automatic (s.18) and manual (s.19) taping sectors from the circulation area; (10) Circulation crossing; (11) Sawdust spread across the floor and machines in the cutting sector (15a, 15b and 15c) and machining center (s.16), close to the automatic taping sector (s.18); (12) Sawdust particles in the air.

(1) Delays in dispatching products; (2) Mixed accesses: entrance of customers and staff, exit of finished materials and entrance of some raw materials (pink line) for the stock of ET and MDF close to the restrooms and kitchen (sectors 5 and 6), and storage room (s.14); (3) Replacement of polyethylene materials (or other polluting materials) by biodegradable materials or cardboards; (4) Waste of cardboard, bubble wrap due to the lack of selective collection and reuse; (5) Economic and environmental costs by transporting finished material; (6) Lack of support bench for packaging procedures; (7) Lack of bench, equipment and technology systems for dispatch control.

(1) Fragmentation in the allocation of waste (byproducts) of MDF/MDP components and carboard in the production area (a.4); (2) Area misused for waste and underused materials; 5 sectors (s.26) of MDF/MDP waste (components with minimum dimensions of approximately $0.40 \mathrm{~m} \times 0.40 \mathrm{~m}$ ), 1 sector with cardboard pieces (s.26) allocated in the floor close to the cardboard stock (s.12), and 5 sectors (s.27) for storing larger MDF/MDP cuts (minimum dimensions of approximately $1.00 \mathrm{~m} \times 2.00 \mathrm{~m}$ ); (3) Area wasted with the allocation of materials for disposal in dumpster K1 (s.28) and MDF components in dumpster K2 (s.29); (4) MDF particles spread across the floor and machines along all cutting sectors (15a,15b and 15c) and machining center (s.16); (5) MDF/MDP sawdust a.6 particles in the air from the extraction of material from the silo due to the lack of sealing of the external space of the extractor (silo) (s.32); (6) Lack of piping in the silo (s.32) to optimize the loading of dumpsters and avoid the dispersion of sawdust particles in the air; (7) No cover on the dumpsters to avoid the dispersion of sawdust upon loading; (8) Costs with company hired to collect the materials for disposal stored in the dumpsters (K1 and K2) and in the silo (sectors 28, 29 and 31); (9) Lack of measurements of the materials allocated to the production area for reuse; (10) Lack of measurements and management of costs associated to the selective collection company for the removal and disposal of materials from dumpsters K1, K2 and the silo (J); (11) Selective collection only of MDF components (K2) and sawdust (s.32), other materials were all together in dumpster (K1) for disposal. 
The design of the SFCMA (Figure 3), zoning plan of production areas (a.) (Figure 4) and the detail of Production Centers (PCs) and sectors (s.) (Figure 5) supported the base layout analyses, being associated to the analyses for the implementation of $\mathrm{CP}$. The analyses resulted in the identification of 48 Critical Points (Table 1), thus leading to a list of opportunities for $\mathrm{CP}$ with improvements in the position of the management infrastructure, staff support, the physical and technological infrastructure, besides the supply and storage of materials and byproducts [28]. In addition, it culminated in the generation of project alternatives and plans for changes, aiming at optimizing inter-related areas between processes and CP. Therefore, the development of a (re)layout process associated to CP was considered an innovative strategy for implementing $\mathrm{CP}$ in the furniture industry.

\section{2. (Re)layout Project as a Strategy for the Implementation of $C P$}

The areas for the (re)layout project were estimated based on the analyses of the movement of materials and metric surveys of each area and sector during the second field visit, besides being based on the diagnostic analyses of flowcharts of the production process, of the spaces for carrying out the activities and the inter-relationship between areas and sectors, as well as considering the environmental waste detected. Moreover, it also consisted of the removal of returns, crossings and floor obstructions.

\subsubsection{Zoning Analysis of the Areas (a.) in the (Re)layout Project}

The zoning plan of the areas in the (re)layout project is presented in Figure 6, locating the entrance of Raw Materials (RMs), byproducts for internal use, machines, equipment, as well as the exit of finished materials and byproducts for external use (industrial symbiosis).

In the (re)layout project, the zoning plan (Figure 6) shows that the access of customers (purple arrow) was separated from the exit of vehicles with finished material (blue dashed arrow). The administration/sales area (a.1) was expanded by $19.12 \mathrm{~m}^{2}$ to allow the creation of an area dedicated to the management of dispatch activities (a.5), close to the access gate for loading finished furniture components, as well as for the displacement of the PPC area close to the production area (a.4), aiming to facilitate management and control processes. In addition, there were also improvements in the interaction and training of the team through the allocation and restructuring of the indoor space for training.

The staff support area (a.2) was enlarged by $23.22 \mathrm{~m}^{2}$, including bathrooms, locker rooms and rest areas. The restructuring of this area aimed at improving the rest conditions for staff, besides ensuring adequate levels of comfort and safety. The project also includes an internal garden area by opening the roof (a.8) for better airing the workspace located between the administration/sales (a.1) and staff support areas (a.4), without crossings.

The (re)layout project also reduced the fragmentation of the stock/storage areas (a.3). The stock of RMs (a.3) was combined and located close to sectors with greater activity in order to minimize time wasted with unnecessary displacements. Regrouping the stocks by type and proximity to the inter-related sectors enabled to make the area available for other uses, namely, by combining the stocks of byproducts for internal use (a.6).

The areas designated to the disposal of materials were removed and replaced by areas for byproducts $\left(\mathrm{a} .6 /\right.$ total of $\left.47.81 \mathrm{~m}^{2}\right)$, both for internal use $\left(6 . \mathrm{a} / 13.49 \mathrm{~m}^{2}\right)$ and external use $\left(6 . \mathrm{b} / 34.32 \mathrm{~m}^{2}\right)$. The reduction was of $51.15 \mathrm{~m}^{2}$, from $98.96 \mathrm{~m}^{2}$ in the base layout to $47.81 \mathrm{~m}^{2}$ in the new proposal, representing a reduction of $51.69 \%$. Furthermore, the byproducts for internal use (6a) were combined and organized in shelves with easy access, close to the entrance of RMs. The byproducts for external reuse (6b) were separated in containers located in each of the PCs, grouped and stored in 2 dumpsters $\left(\mathrm{K} 2 / 3.20 \mathrm{~m}^{2}\right)$ for MDF pieces and splints, 3 barrels (K1) for separating materials (plastic, glue, edging tapes, tow) and the silo (J) $\left(19.40 \mathrm{~m}^{2}\right)$-all parallel to the curbside and close to the entrance of RMs to facilitate delivery and transportation. 


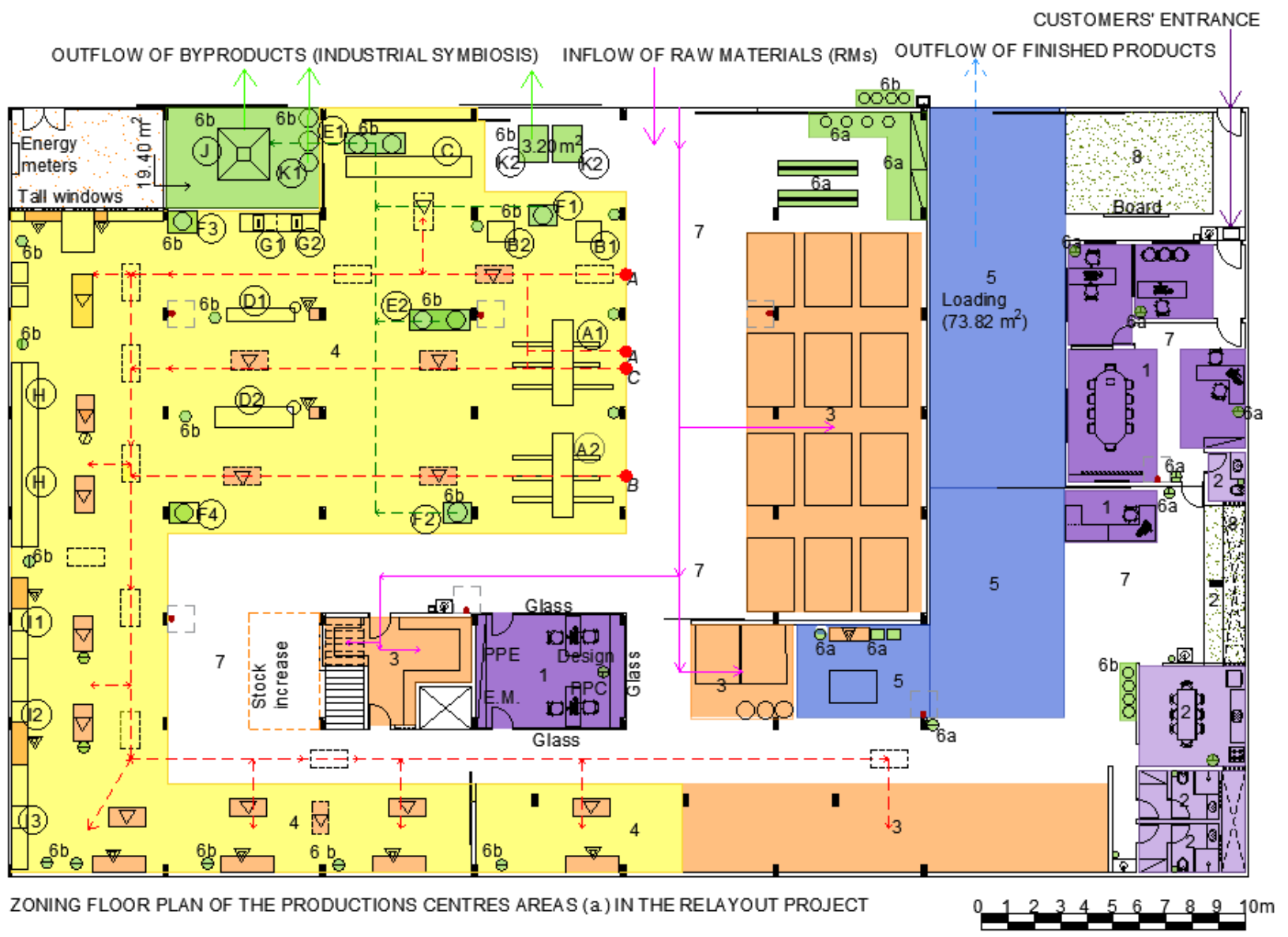

\section{LEGEND:}

AREAS (a.):

a.1 ADMINISTRATION / SALES AREA $\left(75.91 \mathrm{~m}^{2}\right)$

a.2 STAFF SUPPORT AREA $\left(43.23 \mathrm{~m}^{2}\right)$

a.3 STOCK / STORAGE $\left(203.65 \mathrm{~m}^{2}\right)$

$\left(179.96 \mathrm{~m}^{2}+8.37 \mathrm{~m}^{2}+15.32 \mathrm{~m}^{2}=203.65 \mathrm{~m}^{2}\right)$

a.4 $\square$ PRODUCTION (425.06 $\left.\mathrm{m}^{2}\right)$

$\nabla 10$ SHELES FOR STOCK OF RAWMATERIALS IN USE $\left(8.37 \mathrm{~m}^{2}\right)$

$\nabla[\bar{\nabla}] 16$ BENCHES FOR MATERIAL IN PROCESSING, OF WHICH 6 BENCHES WTH WHEELS $\left(15.32 \mathrm{~m}^{2}\right)$

$--\rightarrow$ EXTRACTION PIPES OF SAWDUST PARTICLES (SUSPENDED)

OUTFLOW OF BYPRODUCTS (INDUSTRIAL SYMBIOSIS)

PMOVEMENT OF BENCHES FOR PRODUCTION $(A, B, C)$

MACHINES AND EQUIPMENT:

A1 and A2 - AUTOMATIC HORIZONTAL

WOOD CUTTING PANEL SAW

$B 1$ and B2 - ROUTERS

C- BUSELLATO CNC MACHINING CENTRE

D1 and D2 - AUTOMATIC EDGE GLUER

(TECMATIC and USIKRAFT)

E1 and E2- DUAL SAWDUST COLLECTOR

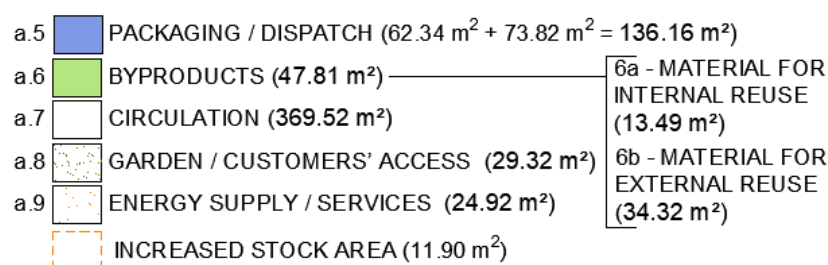

TOTAL FLOOR SPACE $\approx 1.299 .47 \mathrm{~m}^{2}\left(1.225 .65 \mathrm{~m}^{2}+73.82 \mathrm{~m}^{2}\right)$ LAND AREA $(47 \mathrm{~m} \times 30 \mathrm{~m})=1.410 .00 \mathrm{~m}^{2}$

$\longrightarrow$ INFLOW OF CUSTOMERS

$\longrightarrow$ SUPPLY FLOW LINES $(46.75 \mathrm{~m})$

$--\rightarrow$ OUTFLOW OF FINISHED PRODUCTS

PPE - Personal Protective Equipment

E.M. -Environmental Management

PPC - Planning and Production Control

F1 / F2 / F3 / F4 - SAWDUST COLLECTOR G1 and G2-MITRE SAW WITH SLIDE FUNCTION

H - MANUAL / ELECTRIC DRILLS

I1, I2 and I3-BENCH-TYPE DRILLS

QIDEQUIPMENT FOR HYGIENE

(WASHBASIN, SANITIZING CARPET)

\section{$=\approx=-=\square$ ROOF OPENING / AERATION \\ - FIRE EXTINGUISHER $\left(1 \mathrm{~m}^{2}\right)$}

J-SAWDUST COLLECTOR and EXTRACTOR (SILO /

K1 - 3 BARRELRS FOR SELECTIVE COLLECTION / INDUSTRIAL SYMBIOSIS

K2 - 2 DUMPSTERS FOR MDF/MDP SMALL PIECES/SPLINTS (IND. SYMBIOSIS) $\left(3.20 \mathrm{~m}^{2}\right)$

$\ominus \ominus$ COLLECTOR FOR SELECTIVE COLLECTION / - BYPRODUCTS INDUSTRIAL SYMBIOSIS)

Figure 6. Zoning floor plan of the Productions Centers (PCs) areas (a.) in the (re)layout project.

The areas for byproducts were reduced based on the optimization of areas, sectors and flows, organizing and freeing the floor of each Production Center in order to minimize waste in the generating area, machines and equipment, based on plans for optimizing procedures and cutting processes. The proposals for the (re)layout project associated to CP practices include the planning to minimize the disposal of materials in each Production Center 
(generating area), selective collection, cataloguing procedures and storage of material for internal and external use.

The dumpsters (K1 and K2) for disposal, present in the base layout (Figures 4 and 5) were removed and replaced by barrels and dumpsters $\left(1.60 \mathrm{~m}^{2}\right.$ each), minimizing the floor use with materials for external reuse. The area for byproducts (a.6), the barrels and the silo $\left(\mathrm{a} .6 \mathrm{~b} / 19.40 \mathrm{~m}^{2}\right)$ were sealed with a sliding door to avoid the dispersion of wood particles when emptying the silo. The analysis recommends purchasing pipes which fit in the silo, at the same height as the dumpster and with covers to prevent the dispersion of sawdust particles in the air when emptying the dumpster. The external reuse depends on the cooperation between companies involved in the local waste collection.

The areas with floor obstruction were eliminated and the stock being processed, originating from cutting machines and edge taping, were arranged in wheel benches to facilitate transportation, processing of materials and for ergonomic purposes.

\subsubsection{Analysis of the Production Centers (PCs) and Sectors (s.) in the (Re)layout Project}

The floor plan of Production Centers (PCs) and sectors (s.) in the (re)layout project details the integrated zoning proposal, outlining the location of sectors (s.) according to the flow of people and materials, as well as to the position of materials being processed, and of byproducts for internal and external reuse. The sectors (s.) were detailed in Figure 7 of the (re)layout project.

The entrance of customers was separated from the exit of finished material and transferred to the right hand-side of the floor plan, ensuring direct access (purple arrow) to the reception (sector 1 or s.1). To the administration/sales area (a.1), reception (s.1), meeting training (s.2), direction (s.3) and management/sales (s.4) sectors was added a workspace for the dispatch manager (s.5), close to the dispatch area (a.5) and internal access to loading and transport (s.29). In addition, an environmental management area, the PPC and ecodesign sectors (s.6) were also included together to ensure the planning and management of products and manufacturing processes which are ecologically designed to avoid pollutant emissions, with a rational and optimized use of RMs, materials and inputs, thus minimizing the waste of materials, time, areas, sectors and flows in the layout. This also helps to promote the internal and external reuse of materials, for continuous improvements in the production and environmental performance.

The environmental management sector, PPC and ecodesign (s.6), together with the production area (a.4) facilitates planning, management, control and production assessment actions, ensuring the compliance with work safety norms (control in the use of PPEs, for instance), as well as actions more closely related to $\mathrm{CP}$, thus promoting changes in the environmental attitude of the company. The PPC (s.6) can promote actions to organize workspace and prevent materials to avoid overusing benches and floor areas, which can hamper the control and organization in the manufacturing space. With the (re)layout project, the distances from between the PPC (s.6) and the cutting sector with a horizontal section cutter A1 decreased from $76.19 \mathrm{~m}$ (s.15a/Figure 5 of the base layout) to $12.61 \mathrm{~m}$ (s.19a/Figure 7), and to the cutting section with horizontal section cutter A2 from $74.58 \mathrm{~m}$ (s.15b/Figure 5 of the base layout) to $8.34 \mathrm{~m}$ (s.19b/Figure 7).

One of the criteria for implementing CP practices is training [47]. With this objective, the administration/sales area (a.1) was restructured in the (re)layout project, with the inclusion of the meeting and training sector (s.2/Figure 7), ensuring physical and technological mobility enhancements to promote the interaction and continuous training of the team on CP practices. The sector of general management/sales (s.4) remained in the administration/sales area (a.1/Figure 6) as it is responsible for managing resources and purchasing materials, combining directorate strategies (s.3) with information connected to sales (s.1), environmental management, safety, PPC, ecodesign (s.6) and dispatching (s.5). The space designated to $\mathrm{CP}$ training aims at promoting a change of mindset towards the non-generation and minimization of pollutants and waste. 
A rest area (s.11) was designed in the staff support area (a.2), also ensuring the addition of bathrooms (s.10) and locker rooms (s.9), in accordance with norm NR-24 [66]. The fire extinguishers were relocated aiming at improving safety and widening the range (see dashed circles in grey/Figure 7$)$. The areas $\left(1 \mathrm{~m}^{2}\right)$ opposite the extinguishers were unobstructed and outlined, complying with NR-23 [65].

In the (re)layout plan, the MDF/MDP stocks remained close to the access to RMs and next to the cutting machines $(\mathrm{A} 1, \mathrm{~A} 2)$ and routers $(\mathrm{B} 1, \mathrm{~B} 2)$ to facilitate the use and transportation of material, though these were combined. The storage room was relocated to an area close to production and subdivided into two parts: one for stocking Edging Tapes (ET) (s.13a) and another for stocking components and accessories (s.13b). In addition, one area was reserved for future expansions (corresponding to $11.90 \mathrm{~m}^{2}$ ) of the storage room, not jeopardizing the circulation (Figures 6 and 7).

The supply to the storage room with edging tapes and accessories (s.13 and s.13b) and with carboard stocks (s.17) was carried out through one single entrance for RMs, close to the stock area of byproducts for internal reuse (a.6a, Figure 6), MDF/MDP waste sectors (outlined in Figure 5 as critical points in pink) and reducing displacements throughout the processing of edge taping (sectors 23a, 23b and 24), drawers' assembly (s.25), drilling of components / cabinets (s.26) and assembly (sectors 27a, 27b, 27c, 27d).

The area of $28.08 \mathrm{~m}^{2}$ designated to the sock of cardboard in the base layout (s.12, Figure 5) was reduced to $13.82 \mathrm{~m}^{2}$ (s.17/Figure 7). The project highlights the addition of a gate close to the cardboard stocks, to ensure the supply under the same inflow of MPs (pink arrow / Figures 6 and 7), thus improving the control of the areas. The stock of accessories in use were distributed along 10 shelves which can be supplied according to the PPC scheduling.

The production area (a.4) was optimized and integrated. The sectors were reorganized and grouped to ensure flows with no returns or crossings (Figures 6 and 7). The sectors focused on cutting rectangular components (s.19a and s.19b) and ripping curved components (s.20a and s.20b), close to the MDF stock (s.12), were arranged at the central edge of the area, initiating 3 continuous production flow lines: line A for manufacturing tabletops, rectangular and curved connections; line B for manufacturing cabinets, shelves and partitions (rectangular cut); and line C for manufacturing drawers (rectangular cut), as shown by the red dashed line (Figures 6 and 7 ).

Production line A starts in the rectangular cutting sector (s.19 a, section cutter A1) or in the section for ripping curved components (s.20a/router B1 and s.20b/router B2). This line can be then directed towards the machining center (s.21) and/or to the manual edge taping sector (s.24), followed by the finished material stock (s.18). A space allocated to cutting steel profiles was added besides the production line (A) (s.22/miter saws with slide function G1 and G2) with the stock hung to the wall. After cutting, these profiles can be directed towards the sectors focused on the assembly of drawers (s.25) or the assembly of cupboards (sectors 27a, 27b, 27c, 27d), according to the furniture model.

Production line B starts in the sector dedicated to rectangular cuts (s.19b, section cutter A2), following towards the automatic edge taping sector (s.23b/edge tape gluer D2). The furniture pieces can then be directed towards the sector for drilling cupboards (s.26), the assembly of cupboards (s.27a, s.27b, s.27c, s.27d) and/or to the stock of finished material (s.18). In turn, production line $C$ starts in the sector dedicated to rectangular cuts (s.19a, section cutter A1) and is then directed towards the automatic edge taping sector (s.23a, edge tape gluer D1), with the pieces being then transported to the drawers' assembly sector (s.25), then to the stock of finished products (s.18). 
CUSTOMERS ENTRANCE

OUTFLOW OF BYPRODUCTS (INDUSTRIAL SYMBIOSIS) INFLOW OF RAWMATERIALS (RMs) OUTFLOW OF FINISHED PRODUCTS

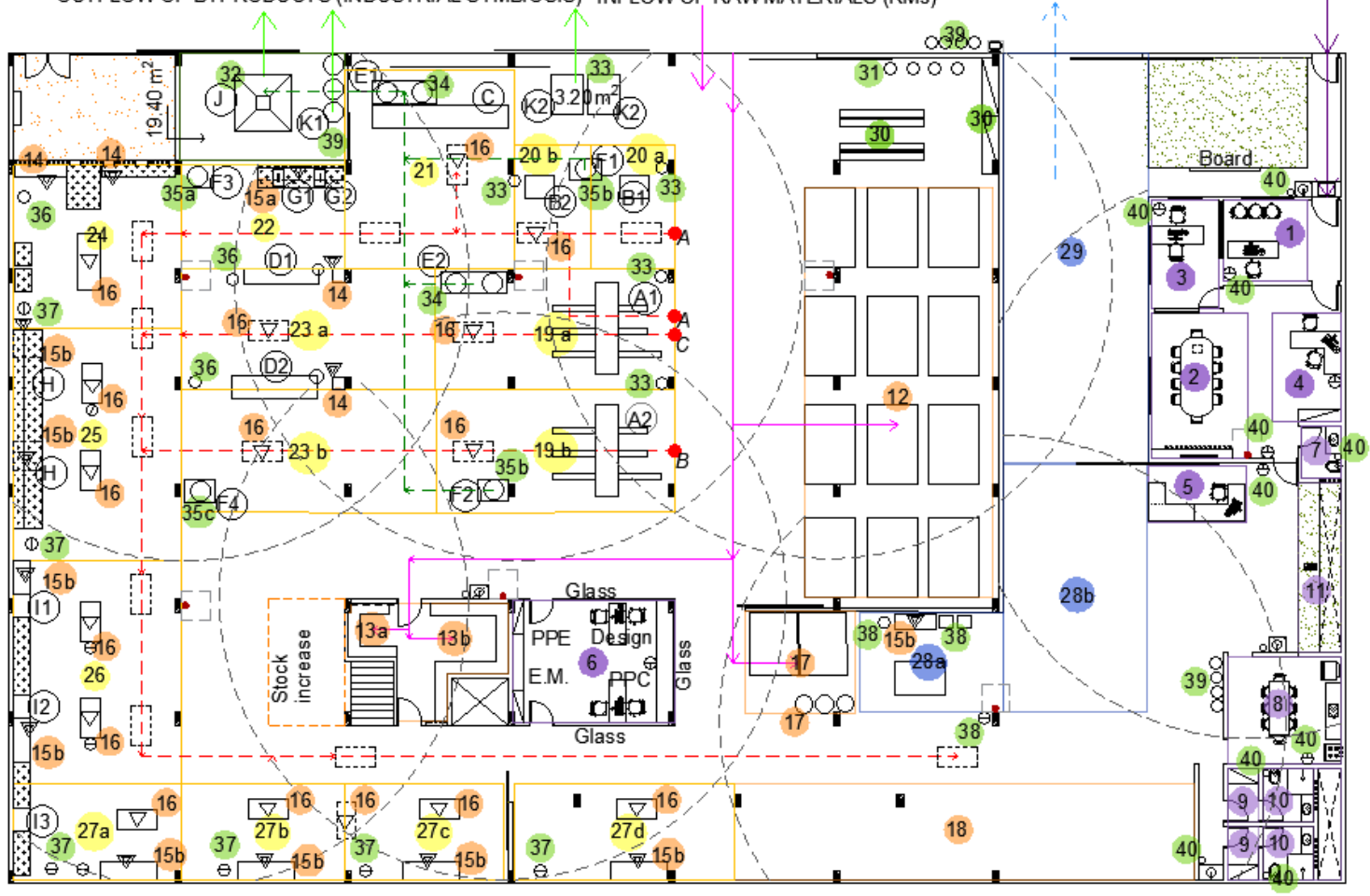

FLOOR PLAN OF THE PRODUCTION CENTERS (PCs) AND SECTORS (s.) IN THE RELAYOUT PROJECT

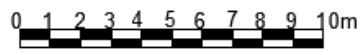

LEGEND:

SECTORS (S.):

S.1 RECEPTION

s. 2 MEETING/TRAINING

S. 3 DIRECTOR

s. 4 MANAGEMENT/ PPC/ SALES

s. 5 MANAGEMENT / DISPATCH

s. 6 ENVIRONMENTAL MANAGEMENT/

PPC and DESIGN

s. 7 RESTROOM

s. 8 FOOD COURT

s. 9 LOCKER ROOMS

s. 10 BATHROOM

s. 11 REST AREA

s. 12 MDF/MDP STOCK

s. 13a STORAGE ROOM OF EDGING

TAPE (ET)

s. 13b STORAGE ROOM FOR

ACCESSORIES

s. 14 ET STOCKINUSE

s. $15 a$ STOCK OF PROFILES OF STEEL

s. $15 \mathrm{~b}$ STOCK OF ACCESSORIES IN USE

- JFIRE EXtinguishers (A, B, C) AREAS OF PRODUCTION CENTRES

GGARDEN ENERGY SUPPLY

B.t. BENCHES

15a $15 \mathrm{~b} \square \square^{10}$ SHELES FOR STOCK OF

s. 16 STOCK OF MATERIAL IN PROCESSING

s. 17 CARDBOARD STOCK

s. 18 STOCK OF FINISHED MATERIAL

s. 19 CUTTING SECTOR (a, b)

s. 20 ROUTERS (a, b) (B1 and B2)

s. 21 CNC MACHINING CENTER

s. 22 STEEL CUT (Mitre saw with slide function)

s. 23 AUTOMATIC GLUING OF ET (rectangular

pieces) (a, b)

s. 24 MANUAL GLUING OF ET (curved pieces)

s. 25 ASSEMBLY DRAWERS

s. 26 CUPBOARDS DRIயING

s. 27 CUPBOARD ASSEMBLY (a, b, c, d)

s. 28a PACKAGING / DISPATCH

s. $28 \mathrm{~b}$ DISPATCH / GARAGE

s. 29) LOADING/TRUCK EXIT

COVERAge RADIUS OF FIRE

$\longrightarrow$ EXTINGUISHERS $(10.00 \mathrm{~m})$

PPE - Personal Protective Equipment E.M. - Environmental Management

- $-=$ - $>$ MOVEMENT OF BENCHES FOR PRODUCTION $(A, B, C)$

$\rightarrow$ INFLOW OF CUSTOMERS

$\longrightarrow$ SUPPLY FLOW LINES $(46.75 \mathrm{~m})$

$-\rightarrow$ OUTFLOW OF FINISHED

PRODUCTS
$\rightarrow$ EXTRACTIONPIPES OF SAWDUST

PARTICLES (SUSPENDED)

16 D $\nabla] 16$ BENCHES FOR MATERIAL IN PROCESSING WITH

$\checkmark$ SUPPORT 16 BENCHES FOR MATERIAL IN PROCESSING WITH s. 30 BYPRODUCTS (MDF/MDP)

s. 31 BYPRODUCTS (STEEL)

s. 32 SILO AND EXTRACTOR / SAWDUST BYPRODUCT

s. 33 SELECTIVE COLLECTION (MDFMDP)

s. 34 SELECTIVE COLLECTION / SAWDUST / DUAL COUECTOR

s. 35a SELECTIVE COUECTION / STEEL DUST / COLLECTOR

s. 35b SELECTIVE COUECTION / SAWDUST / COLLECTOR

s. 35 C SELECTIVE COUECTION (MDFMDP+GLUE+EDGING TAPES)

s. 36 SELECTIVE COLLECTION (MDFMDP+GLUE+EDGING TAPES)

s. 37 SELECTIVE COLLECTION (PLASTIC AND SAWDUST FROM

DRIயING)

s. 38 SELECTIVE COLLECTION (CARDBOARDIBUBBLE WRAP)

s. 39 SELECTIVE COLLECTION (IND. SYMBIOSIS)

s. 40 SELECTIVE COLLECTION (PAPER/PLASTIC/ORGANIC

CONTAMINATED PAPER)

MACHINES AND EQUIPMENT

A1 and A2-AUTOMATIC HORIZONTAL WOOD CUTTING PANEL SAW

$B 1$ and B2- ROUTERS

C- BUSELLATO CNC MACHINING CENTRE

D1 and D2- AUT OMATIC EDGE GLUER (TECMATIC and USIKRAFT)

E1 and E2-DUAL SAWDUST COLECTOR

F1/F2/F3/F4-SAWDUST COLLECTOR

G1 and G2-MITRE SAW WITH SLIDE FUNCTION

H- MANUAL/ ELECTRIC DRILLS

I1, 12 and 13 -BENCH-TYPE DRILLS

J-SAWDUST COLECTOR and EXTRACTOR (SILO) (IND.

SYMBIOSIS

K1 - 3 BARRELRS FOR SELECTIVE COLIECTION (IND. SYMBIOSIS) K2 - 2 DUMPSTERS FOR MDFMDP SMALL PIECES / SPUNTS (IND.

SYMBIOSIS) (1.60 $\mathrm{m}^{2}$ cada) (3.20 $\mathrm{m}^{2}$ área total) [प]

TRE ROOF OPENING IAERATION

$\oplus \ominus \circ$ COUECTOR FOR SELECTIVE COUECTION / BYPRODUCTS

Figure 7. Floor plan of the Production Centers (PCs) and sectors (s.) in the (re)layout project.

The sector allocated to packaging/dispatching (s.28a) remained in the end of the process next to the stock of finished material (s.18). The dispatch/garage sector (s.28b) 
and management/dispatch (s.5) were arranged together in the indoor area of the company. The following opportunities identified by the (re)layout project associated to $\mathrm{CP}$ for sector 28a can be pointed out: avoid or minimize the use of plastic material produced with polyethylene, avoid the disposal and ensure selective waste management, replace polluting plastic materials by biodegradable and/or cardboard, selective waste management of wood material waste and promote their reuse. The physical space for these activities was restructured with the introduction of a support bench, a shelf, dumpsters and management procedures, besides the control and assessment of $\mathrm{CP}$ practices.

In the (re)layout project, the byproducts were subdivided by type (MDF/MDP waste, MDF/MDP parts and splints, steel, sawdust, plastic, MDF + glue + edge tape compound, cardboard, paper, sawdust from drilling, organic waste, glue and solvent packages, tow, contaminated paper). The dumpsters were located in the sector and close to the access to RMs to ensure selective waste management and internal and/or external reuse (indication of the type of material), besides the appropriate disposal by a specialized company.

The pipes for collecting sawdust were relocated, suspended and rearranged in a perpendicular position to the silo (s.32), which remained parallel to the curbside to facilitate the collection, though now in a sealed environment, preventing the dispersion of sawdust particles in the air and surroundings. In the (re)layout project, the scattered MDF/MDP waste which was leaning on the walls in the base layout (sectors 26 and 27/Figure 5) was grouped and stored in sector 30 (s.39) for reuse. In the (re)layout project, the byproducts originating from the section cutter machines (A1, A2), routers (B1, B2) and machining center $(\mathrm{C})$ can be directed to the byproducts area after selection and cataloguing procedures (a.6a/sector 30/Figures 6 and 7) through wheel benches.

Following the (re)layout project, the existing and designed data were compared, having observed the optimization of the parameters as a result of the (re)layout project, associated to $\mathrm{CP}$ practices, thus validating the study. Table 2 compares the use of zoning areas and sectors in the baseline scenario, the estimations of the areas proposed in the (re)layout project and the influence of the (re)layout project on CP practices.

Table 2. Comparison between the base and designed layout from the zoning analysis. Influence of the (re)layout project on CP.

\begin{tabular}{|c|c|c|c|c|c|c|}
\hline $\begin{array}{l}\text { Layout Project } \\
\text { and CP Factors }\end{array}$ & Indicator & $\begin{array}{c}\text { Existing } \\
\text { Layout }\left(\mathrm{m}^{2}\right)\end{array}$ & $\begin{array}{c}\text { Proposed } \\
\text { Layout }\left(\mathrm{m}^{2}\right)\end{array}$ & \multicolumn{2}{|c|}{$\begin{array}{c}\text { Influence of the (Re)layout Project } \\
\text { on CP Practices }\end{array}$} & $\begin{array}{c}\text { Criteria and } \\
\text { Attributes of CP for } \\
\text { Reaching } \\
\text { Links [+] with CP }\end{array}$ \\
\hline Changes; & \multicolumn{6}{|c|}{ Design of areas (a.) $\left(\mathrm{m}^{2}\right)$} \\
\hline $\begin{array}{l}\text { Services; Labor } \\
\text { force; Eco } \\
\text { materials and } \\
\text { byproducts; } \\
\text { Stock, storage } \\
\text { and Waiting time; } \\
\text { Machines, } \\
\text { equipment and } \\
\text { systems; Eco } \\
\text { building; }\end{array}$ & $\begin{array}{l}\text { (a.1) } \\
\text { Administra- } \\
\text { tion/sales }\end{array}$ & 56.79 & 75.91 & $\begin{array}{l}{[+] 19.12 \mathrm{~m}^{2}} \\
=\text { increase of } \\
25.18 \% \text { when } \\
\text { compared to } \\
\text { previous area }\end{array}$ & $\begin{array}{c}\text { [+] Expansion of } \\
\text { management area. } \\
\text { [+] Training. } \\
\text { [+] Preventive } \\
\text { Environmental } \\
\text { management, PPC, } \\
\text { safety and ecodesing. } \\
\text { [+] Dispatch } \\
\text { management. }\end{array}$ & $\begin{array}{c}\text { Organization. } \\
\text { Staff training. } \\
\text { [+] Integration between } \\
\text { EM/PPC/Ecodesign. } \\
\text { [+] Team interaction. }[+] \\
\text { Management } \\
\text { of changes. }\end{array}$ \\
\hline \multirow[t]{2}{*}{$\begin{array}{l}\text { Movement of } \\
\text { materials, people } \\
\text { and information; } \\
\text { Dispatch and } \\
\text { delivery. }\end{array}$} & $\begin{array}{c}(\text { a.2) } \\
\text { Staff support }\end{array}$ & 20.01 & 43.23 & $\begin{array}{c}{[+] 23.22 \mathrm{~m}^{2}} \\
=\text { increase of } \\
53.71 \% \text { when } \\
\text { compared to the } \\
\text { previous area }\end{array}$ & $\begin{array}{c}\text { [+] Expansion of staff } \\
\text { support areas. [+] } \\
\text { Locker rooms, } \\
\text { bathrooms and rest } \\
\text { areas. [+] Risk } \\
\text { minimization (RMs). }\end{array}$ & $\begin{array}{l}\text { Organization. Staff } \\
\text { training. }[+] \text { Comfort } \\
\text { and safety. }[+] \\
\text { Minimization of } \\
\text { environmental risks. [+] } \\
\text { Commitment. }\end{array}$ \\
\hline & $\begin{array}{c}\text { (a.3) } \\
\text { Stock/ } \\
\text { storage (total) }\end{array}$ & $\begin{array}{c}273.66 \\
(217.57+56.09)\end{array}$ & 203.65 & $\begin{array}{l}{[-] 70.01 \mathrm{~m}^{2} \text { in }} \\
\text { the total area } \\
=\text { decrease of } \\
25.59 \% \text { when } \\
\text { compared to the } \\
\text { previous area }\end{array}$ & $\begin{array}{c}\text { [+] Rearrangement of } \\
70.01 \mathrm{~m}^{2} \text { to } \\
\text { other areas. } \\
{[+] \text { Proximity to }} \\
\text { production area. } \\
{[+] \text { Optimization of }} \\
\text { the inflow of RMs. } \\
{[+] \text { Optimization of }} \\
\text { the area, sector } \\
\text { and flow. }\end{array}$ & $\begin{array}{l}\text { Organization. Systems } \\
\text { and technologies. } \\
\text { [+] Physical/visual } \\
\text { management of } \\
\text { materials to } \\
\text { avoid waste. } \\
\text { [+] Integration of } \\
\text { projects to maximize the } \\
\text { use of materials. }\end{array}$ \\
\hline
\end{tabular}


Table 2. Cont.

\begin{tabular}{|c|c|c|c|c|c|c|}
\hline $\begin{array}{l}\text { Layout Project } \\
\text { and CP Factors }\end{array}$ & Indicator & $\begin{array}{c}\text { Existing } \\
\text { Layout }\left(\mathrm{m}^{2}\right)\end{array}$ & $\begin{array}{c}\text { Proposed } \\
\text { Layout }\left(\mathrm{m}^{2}\right)\end{array}$ & \multicolumn{2}{|c|}{$\begin{array}{c}\text { Influence of the (Re)layout Project } \\
\text { on CP Practices }\end{array}$} & $\begin{array}{c}\text { Criteria and } \\
\text { Attributes of CP for } \\
\text { Reaching } \\
\text { Links [+] with CP }\end{array}$ \\
\hline & $\begin{array}{c}\text { (a.3/floor) Area } \\
\text { with cut } \\
\text { components } \\
\text { being processed }\end{array}$ & $\begin{array}{l}56.09 \\
\text { On the floor }\end{array}$ & $\begin{array}{l}15.32 \\
\text { Located } \\
\text { above the } \\
\text { floor, on } \\
\text { benches }\end{array}$ & \multicolumn{2}{|r|}{$\begin{array}{c}\text { [+] Rearrangement } \\
40.77 \mathrm{~m}^{2} \text { to } \\
\text { other areas. } \\
{[+] \text { Benches } / \text { wheel }} \\
\text { benches. } \\
\text { [+] Floor } \\
\text { unobstruction and } \\
\text { flexibility. }\end{array}$} & $\begin{array}{l}\text { Organization. Systems } \\
\text { and technologies. } \\
\text { [+] Optimization of } \\
\text { areas to avoid waste. } \\
\text { [+] Ergonomics. }\end{array}$ \\
\hline & $\begin{array}{l}(\text { a.4) } \\
\text { Production }\end{array}$ & 283.36 & 425.06 & $\begin{array}{c}{[+] 141.70 \mathrm{~m}^{2}} \\
=\text { increase of } \\
33.33 \% \text { when } \\
\text { compared to the } \\
\text { previous area }\end{array}$ & $\begin{array}{c}\text { [+] Expansion of } \\
\text { production area. } \\
\text { [+] Greater } \\
\text { production capacity. } \\
\text { [+] Production } \\
\text { management. } \\
\text { [+]Optimization. }\end{array}$ & $\begin{array}{l}\text { Organization. Systems } \\
\text { and technologies. } \\
{[+] \text { Integration of the }} \\
\text { systems to avoid } \\
\text { production and } \\
\text { environmental waste. } \\
{[+] \text { Safety. }}\end{array}$ \\
\hline & $\begin{array}{c}\text { (a.5/ } \\
\text { internal) } \\
\text { Packaging/ } \\
\text { dispatch }\end{array}$ & 46.97 & 62.34 & $\begin{array}{l}{[+] 15.37 \mathrm{~m}^{2}} \\
=\text { increase of } \\
24.65 \% \text { when } \\
\text { compared to the } \\
\text { previous area }\end{array}$ & $\begin{array}{l}\text { [+] Expansion of the } \\
\text { sector's capacity of } \\
\text { packaging and } \\
\text { dispatching. [+] Area } \\
\text { for non-polluting } \\
\text { materials. [+] Area for } \\
\text { collection and reuse. }\end{array}$ & $\begin{array}{c}\text { Organization. Staff } \\
\text { training. Systems and } \\
\text { technologies. } \\
{[+] \text { Non-generation }} \\
\text { and/or minimization of } \\
\text { pollutants. [+] } \\
\text { Collection and reuse. }\end{array}$ \\
\hline & $\begin{array}{l}\text { (a.5/ } \\
\text { external) } \\
\text { loading/ } \\
\text { unloading }\end{array}$ & 73.82 & 73.82 & Unchanged & $\begin{array}{l}\text { [+] Separation } \\
\text { between the loading } \\
\text { and unloading area } \\
\text { and the entrance to } \\
\text { customers }\end{array}$ & $\begin{array}{c}\text { Organization. Safety } \\
\text { and staff. } \\
{[+] \text { Safety }}\end{array}$ \\
\hline & $\begin{array}{l}\text { (a.6) } \\
\text { Byproducts }\end{array}$ & 98.96 & 47.81 & $\begin{array}{c}{[-] 51.15 \mathrm{~m}^{2}} \\
=\text { decrease of } \\
51.69 \% \text { when } \\
\text { compared to the } \\
\text { previous area }\end{array}$ & $\begin{array}{c}{[+] \text { Rearrangement of }} \\
51.15 \mathrm{~m}^{2} \text { to } \\
\text { other areas. } \\
\text { [+] Design for the } \\
\text { non-generation } \\
\text { and/or reduction of } \\
\text { production and } \\
\text { environmental waste. }\end{array}$ & $\begin{array}{l}\text { Organization. Staff } \\
\text { training. Systems and } \\
\text { technologies. } \\
\text { [+] Integrated projects } \\
\text { for internal and/or } \\
\text { external reuse. }\end{array}$ \\
\hline & $\begin{array}{l}\text { (a.6a) } \\
\text { Byproducts/ } \\
\text { Internal reuse }\end{array}$ & $\begin{array}{l}26.90 \\
\text { For reuse }\end{array}$ & 13.49 & $\begin{array}{c}{[-] 13.41 \mathrm{~m}^{2}} \\
=\text { decrease of } \\
49.86 \% \text { when } \\
\text { compared to the } \\
\text { previous area }\end{array}$ & $\begin{array}{c}{[+] \text { Rearrangement of }} \\
13.41 \mathrm{~m}^{2} \text { to other } \\
\text { areas. [+] Projection } \\
\text { for the } \\
\text { non-generation } \\
\text { and/or reduction of } \\
\text { production and } \\
\text { environmental waste. }\end{array}$ & $\begin{array}{l}{[+] \text { Projects for the }} \\
\text { non-generation and/or } \\
\text { reduction of byproducts. } \\
{[+] \text { Optimization of }} \\
\text { areas. } \\
{[+] \text { Collection, }} \\
\text { organization for reuse. }\end{array}$ \\
\hline & $\begin{array}{l}\text { (a.6b) } \\
\text { Byprod- } \\
\text { ucts/external } \\
\text { reuse }\end{array}$ & $\begin{array}{l}72.06 \\
\text { For disposal }\end{array}$ & $\begin{array}{l}34.32 \\
\text { For external } \\
\text { reuse }\end{array}$ & $\begin{array}{c}{[-] 37.74 \mathrm{~m}^{2}} \\
=\text { decrease of } \\
52.38 \% \text { when } \\
\text { compared to the } \\
\text { previous area }\end{array}$ & $\begin{array}{c}{[+] \text { Rearrangement of }} \\
37.74 \mathrm{~m}^{2} \text { to other } \\
\text { areas. [+] Projection } \\
\text { for the } \\
\text { non-generation } \\
\text { and/or reduction of } \\
\text { production and } \\
\text { environmental waste. }\end{array}$ & $\begin{array}{l}\text { [+] Association of } \\
\text { projects for external } \\
\text { reuse and industrial } \\
\text { symbiosis; } \\
\text { [+] Organization for } \\
\text { selective collection; }[+] \\
\text { Reuse. }\end{array}$ \\
\hline & $\begin{array}{l}(\text { a.7) } \\
\text { Circulation }\end{array}$ & 445.90 & 369.52 & $\begin{array}{c}{[-] 76.38 \mathrm{~m}^{2}} \\
=\text { decrease of } \\
17.13 \% .\end{array}$ & $\begin{array}{l}{[+] \text { Rearrangement of }} \\
76.38 \mathrm{~m}^{2} \text { to other } \\
\text { areas. [+] } \\
\text { Optimization of the } \\
\text { circulation flow. }\end{array}$ & $\begin{array}{l}\text { Systems and } \\
\text { technologies. } \\
{[+] \text { Optimization of the }} \\
\text { area, sector and flow. }\end{array}$ \\
\hline
\end{tabular}


The data presented in Table 2 confirm the theoretical and practical contribution of this study and that the (re)layout project integrated with the CP helps to promote improvements in areas, sectors and processes, minimizing production waste and helping to overcome barriers for the implementation of CP. Moreover, it contributes towards meeting SDGs in a practical way, through improvements in safety, ergonomics, health and well-being of workers (SDG 3) in all areas of the company; efficient production areas (a.4) with the use of resources, cleaner technologies and processes, as well as the integration of systems for the non-generation of waste (SDG 9); stock areas (a.3) which prevent waste generation and maximize the use of resources (SDG 15); dispatching (a.5) and byproducts (a.6) which facilitate the non-generation of pollutants, the control and internal/external reuse (SDG 15).

\section{Discussion}

By carrying out the (re)layout project integrated to $\mathrm{CP}$ practices, the administrative area of the company (a.1/Table 2) was expanded by $25.18 \%$ when compared to the base layout, having a positive influence on the arrangement of the physical spaces for activities related to management, the integration of preventive Environmental Management (EM), safety and ecodesign to the Production Planning and Control (PPC), as well as dispatching activities. With the expansion, it was possible to organize the physical space to ensure a dedicated space for meetings, team interaction, the presentation of projects and training, and improving security. The organization, training and people management criteria and attributes for the implementation of CP [47] were fulfilled. The (re)layout project integrated to $\mathrm{CP}$ practices thus strategically contributes to the organization of the physical space of management, training and support areas to facilitate the integration, management of routines, changes and overcoming technical barriers that contemplate SDG 9, 12 and 15.

The expansion of supports areas by $53.71 \%$ when compared to the base layout aimed at ensuring that the work environment was safe and comfortable for staff. The change was related to the rearrangement of the storage area close to the production area to facilitate supply, as well as to the inclusion of bathrooms, locker rooms and rest areas to minimize risks and comply with norm NR-24 [66] on the sanitary and comfort conditions in the workspace. The production area was expanded by $283.36 \mathrm{~m}^{2}$ to $425.06 \mathrm{~m}^{2}$, thus, an increase of $33.33 \%$ when compared to the existing area, ensuring greater floor production capacity.

With the relocation of the storage room, the supply flow lines for the inflow of RMs (pink line) were reduced by $86.96 \mathrm{~m}$ (base layout /Figure 5) to $46.75 \mathrm{~m}$ (in the (re)layout project, Figure 7) - this reduction represents a decrease of $46.24 \%$ in the supply flows. The stock/storage area was reduced by $273.66 \mathrm{~m}^{2}$ to $203.65 \mathrm{~m}^{2}$. In addition, the total area was reduced by $70.01 \mathrm{~m}^{2}$, corresponding to a $25.59 \%$ decrease when compared to the base layout. This decrease was obtained from the separation of the access to RMs, as well as to the access of customers and the exit of finished material, and by grouping materials for storage, the location of stocks aiming at reducing displacements of inter-related areas.

In the (re)layout plan, the area occupied with material being processed changed from $56.09 \mathrm{~m}^{2}$ to $15.32 \mathrm{~m}^{2}$ arranged above the floor, in wheels benches, promoting the reduction of waste and ergonomic improvements. Critical Points were eliminated from the areas and sectors, ensuring the clearance of floor areas.

The (re)layout project associated to CP practices enabled to increase the area for dispatch/packaging (a.5) by $15.37 \mathrm{~m}^{2}$ (a $24.65 \%$ increase) and focus on minimizing the generation of production waste, optimizing processes and the physical space for preventing delivery delays. Moreover, the area was interconnected with the dispatch management sector (s.5), enabling improvements in the management of orders, delivery and dispatch dates. The areas allocated to byproducts (a.6) were rearranged and reallocated for internal and external reuse, with the specification of the type of materials for such. The areas for the disposal of materials (considered waste) were eliminated. The areas for byproducts (a.6/Table 2) were reduced from $98.96 \mathrm{~m}^{2}$ to $47.81 \mathrm{~m}^{2}$, corresponding to a decrease of $51.69 \%$ when compared to the base layout. These changes and the rearrangement of dumpsters facilitate selective waste collection, as well as internal/external reuse, thus promoting 
the minimization of production waste, optimizing processes and clearing floor areas and ensuring sustainable operations.

The (re)layout project integrated to $\mathrm{CP}$ practices fulfilled the criteria and attributes associated to systems and technologies for the implementation for CP [47] in the stock (a.3/Table 2), production (a.4/Table 2), dispatch/packaging (a.5/Table 2) and byproduct areas (a.6/Table 2). Thus, it ensures an innovative link which contributes towards overcoming technical barriers related to the implementation of CP practices, discussed by $[20,39,40]$, having a positive influence on the organization of physical spaces for storage, production, dispatch/packaging, byproducts and circulation, and promotes improvements in areas, sectors and processes, minimizing production losses. The results confirm that the (re)layout project can be used as a strategy for the implementation of $\mathrm{CP}$ practices. These studies are innovative, and are in line with the research carried out by Lins and César (2015) [21] and Lins et al. (2020) [28] on layout and CP.

\section{Conclusions}

The data of the present research confirm the hypothesis that a (re)layout project is a strategy for the implementation of CP in SMEs, boosting changes in areas and sectors, thus promoting the optimization of processes and the minimizing waste and production losses. In this regard, integrating (re)layout projects to $\mathrm{CP}$ practices is characterized as innovation in the workspace, with the reduction of environmental impacts.

In the case study, the (re)layout project integrated to $\mathrm{CP}$ ensured the increase of the administrative area by $25.18 \%$, having a positive influence on the management space aiming towards the integration of the Environmental Management (EM), Ecodesign and PPC and promoting changes. Moreover, it reduced the stock/storage area by $36.59 \%$ and the area for materials in processing by $72.69 \%$ by rearranging and optimizing areas and sectors, besides clearing floor spaces. The area allocated to byproducts for reuse was reduced by $51.69 \%$, with the areas for disposing materials being removed. In addition, the floor capacity was increased, with the production area expanded by $33.33 \%$ from the optimization and association of areas and sectors which are interrelated, reducing waste and areas with floor obstruction and production losses.

The methodology used for carrying out the (re)layout project integrated to $\mathrm{CP}$ practices enabled to fulfil the objective of this research and optimize processes, areas and sectors through a (re)layout project, strategically contributing to the implementation of Cleaner Production (CP). The (re)layout associated to the implementation of $\mathrm{CP}$ in the furniture manufacturing industry used as a case study herein optimized areas and sectors, reducing production losses and the waste of resources; thus, optimizing processes which extrapolate the internal industrial space and interfere in socio environmental well-being.

The (re)layout project is a strategy for the implementation of $\mathrm{CP}$ practices in physical industrial spaces, fulfilling criteria and attributes that, when associated, establish and boost a positive and innovative link between two different fields of knowledge (layout and CP), contributing to the economic and socio-environmental sustainability, as well as towards meeting Sustainable Development Goals (SDGs) 3, 9, 12 and 15.

In practical terms, (re)layout projects integrated to $\mathrm{CP}$ facilitate the management and optimization of areas, sectors and process flows, improving production capacity through the reduction of production losses and optimizing the use of materials and inputs. Furthermore, it promotes the reuse of materials, the quality of the work environment, of processes and products, besides reducing costs and waste.

One of the contributions of the present study in the field of sustainability includes broadening the dialogue on the strategic importance of sustainable physical industrial projects integrated with Cleaner Production (CP), tackling aspects related to the optimization of processes which extrapolate the internal industrial environment.

Therefore, it is an innovative contribution which establishes a new perspective for integration of (re)layout projects with the implementation of $\mathrm{CP}$, to mapping dumpsters for 
byproducts, maximizing the use materials, boosting the reduction of production losses and the waste of natural resources.

The analyses of areas, sectors and processes integrated with the analyses of production losses can be characterized as a strategy for the implementation of $\mathrm{CP}$ practices in the furniture industry, promoting changes which can optimize processes and ensure continuous internal changes, thus encouraging investments and the commitment of companies for greater production performance and sustainability. In this regard, the present research is an innovative proposal that establishes a new theoretical and practical perspective for (re)layout projects (physical arrangements or layouts) integrated into Cleaner Production, consisting of a novelty in the literature which can be replicated in other small businesses.

Author Contributions: This article was developed by all authors, with special attention to the authors S.F.C. and A.K. for the contact established with NGD for the exchange of knowledge, text review, analyses, proposals and reflections on the work; P.S.L. for developing the work and data collection during the technical visits with the company in study, analyses, proposals, literature review, drawing the floor plans, layout and writing the article; Á.L.Q.R.eS.R. for the support in the technical visits, analyses, reviews and discussions, and R.D.A.C. for the revision, analysis and contributions to the methodology developed; E.A.D.M. for the contact with the company, company in technical visits, photographs and discussions. All authors have read and agreed to the published version of the manuscript.

Funding: This research did not receive any external funding.

Institutional Review Board Statement: Not applicable.

Informed Consent Statement: Not applicable.

Data Availability Statement: Not applicable.

Acknowledgments: This study was possible due to the qualification program (Masters and $\mathrm{PhD}$ ) established between the Industrial Engineering Department from the Federal University of Bahia (PEI-UFBA) and the Federal Institute of Alagoas (IFAL); the support of the UFBA Wood Laboratory (MadLab); the Design Management Center (NGD) of the Federal University of Santa Catarina (UFSC) and the IFAL Interdisciplinary Study Group (GEID); as well as the furniture manufacturing company for office purposes located in Palhoça (SC/Brazil) for their reception, availability and interest in supporting and collaborating with the necessary information whenever requested. A special thanks to the contribution of Eugenio Andrés Díaz Merino, who coordinated the contact with the host company and follow-up the technical visit; and Armando Tanimoto, from the Federal Institute of Bahia (IFBA).

Conflicts of Interest: The authors state that there are no conflicts of interest.

\section{References}

1. Chung, I. United Nations Environment Programme, Division of Technology, Industry \& Economics France (UNEP/DTIE France). Environmental Agreements and Cleaner Production. Questions and Answers, 2006. UNEP/DTIE France, Printing Centro de Producción más Limpia, Costa Rica. 2006. Available online: https://www.unep.org/resources/report/environmentalagreements-and-cleaner-production (accessed on 20 May 2021).

2. United Nations Industrial Development Organization (UNIDO). UNIDO's Environment Solution: Resource Efficient and Cleaner Production. Available online: https:/ / www.unido.org/sites/default/files/2017-05/RECP_EN_0.pdf (accessed on 20 May 2021).

3. Da Silva, G.C.S.; De Medeiros, D.D. Metodologia de Checkland aplicada à implementação da Produção mais Limpa em serviços. Gest. Prod. 2006, 13, 411-422. (In Portuguese) [CrossRef]

4. Schneider, P.; Oswald, K.; Riedel, W.; Meyer, A.; Schiller, G.; Bimesmeier, T.; Thi, V.A.P.; Khac, L.N. Engineering Perspectives and Environmental Life Cycle Optimization to Enhance Aggregate Mining in Vietnam. Sustainability 2018, 10, 525. [CrossRef]

5. LaGrega, M.D.; Buckingham, P.L.; Evans, J.C. Hazardous Waste Management; MacGraw: New York, NY, USA, 1994.

6. Guimarães, J.C.F.; Severo, E.A.; Senna, P. Cleaner Production Criteria and Project Management Maturity: A Structural Equation Modeling Analysis in Brazilian Industries. In Proceedings of the 5th International Workshop Advances in Cleaner Production, São Paulo, Brazil, 20-22 May 2015. Available online: http:/ / www.advancesincleanerproduction.net/fifth/files/sessoes /4B/2/ guimaraes_et_al_academic.pdf (accessed on 10 September 2020).

7. Guimarães, J.C.F.; Severo, E.A.; Rocha, J.M.; Olea, P.M. Decision Criteria for the Implementation of Cleaner Production: The Case of Five Leading Companies in Southern Brazil. Espacios 2013, 34, 1-12. Available online: http:/ /www.revistaespacios.com/a13v3 4n12/13341204.html (accessed on 10 September 2020). 
8. Neto, G.C.O.; Shibao, F.Y.; Filho, M.G. The State of Research on Cleaner Production in Brazil. Rev. Adm. Empres. 2016, 56, 547-577. [CrossRef]

9. Neto, G.C.O.; Correia, J.M.F.; Silva, P.C.; Sanches, A.G.d.O.; Lucato, W.C. Cleaner Production in the textile industry and its relationship to sustainable development goals. J. Clean. Prod. 2019, 228, 1514-1525. [CrossRef]

10. Nações Unidas in Brazil (ONU/Brazil). Sobre o Nosso Trabalho Para Alcançar os Objetivos de Desenvolvimento Sustentável no Brasil. Available online: https://brasil.un.org/pt-br/sdgs (accessed on 9 November 2021). (In Portuguese)

11. Fernandes, J.V.G.; Gonçalves, E.; Andrade, J.C.S.; Kiperstok, A. Introduzindo práticas de produção mais limpa em sistemas de gestão ambiental certificáveis: Uma proposta prática. Rev. Eng. Sanit. Ambient. 2001, 6, 157-164. Available online: http: / / abes-dn.org.br/publicacoes/engenharia/resaonline/v6n34/v6n34a06.pdf (accessed on 10 September 2020). (In Portuguese).

12. Marujo, L.G.; Carvalho, D.; Leitão, M.N. Otimização de layout utilizando-se o SLP combinado com teoria das filas: Um estudo de caso em uma oficina de rodas e freios de aeronaves. Rev. Gest. Ind. 2010, 6, 93-109. (In Portuguese) [CrossRef]

13. Slack, N.; Johnston, R.; Brandon-Jones, A. Administração da Produção, 8th ed.; Atlas: São Paulo, Brazil, 2018. (In Portuguese)

14. Saravanan, M.; Arulkumar, P.V. An artificial bee colony algorithm for design and optimize the fixed area layout problems. Int. J. Adv. Manuf. Technol. 2015, 78, 2079-2095. [CrossRef]

15. Corrêa, H.L.; Corrêa, C.A. Administração de Produção e Operações: Manufatura e Serviços: Uma Abordagem Estratégica; Editora Atlas SA: São Paulo, Brazil, 2016. (In Portuguese)

16. Krajewsky, L.; Ritzman, L.; Malhotra, M. Administração de Produção e Operações, 8th ed.; Pearson Prentice Hall: São Paulo, Brazil, 2014. (In Portuguese)

17. Centro Nacional de Tecnologias Limpas (CNTL). Implementação de Programas de Produção Mais Limpa (Série Manuais de Produção Mais Limpa). 2003. Available online: www.pha.poli.usp.br/LeArq.aspx?id\%5Farq=7985 (accessed on 12 June 2020). (In Portuguese)

18. Centro Nacional de Tecnologias Limpas (CNTL). Diagnóstico Ambiental e de Processo (Série Manuais de Produção Mais Limpa). 2003. Available online: https://www.senairs.org.br/documentos/serie-manuais-de-producao-mais-limpa-diagnosticoambiental-e-de-processo (accessed on 12 June 2020). (In Portuguese).

19. Rentes, A.F. Projeto de Fábrica enxuta: Alta performance já na concepção da fábrica. Rev. Bras. Eng. 2013. Available online: http:/ / www.brasilengenharia.com/portal/images/stories/revistas/edicao614/614_leitor_projeto.pdf (accessed on 19 April 2021). (In Portuguese)

20. Leite, R.; Amorim, M.; Rodrigues, M.; Neto, G.O. Overcoming Barriers for Adopting Cleaner Production: A Case Study in Brazilian Small Metal-Mechanic Companies. Sustainability 2019, 11, 4808. [CrossRef]

21. Lins, P.S.; César, S.F. Arranjo físico (layout) e produção mais limpa (P + L): Uma discussão teórica. In Proceedings of the 5th International Workshop Advances in Cleaner Production, São Paulo, Brazil, 20-22 May 2015. Available online: http: //www.advancesincleanerproduction.net/fifth/files/sessoes/5B/2/lins_ps_et_al_academic_03.pdf (accessed on 19 April 2021). (In Portuguese)

22. Aguilar, C.M.G.; Panameño, R.; Velazquez, A.P.; Álvarez, B.E.A.; Kiperstok, A.; César, S.F. Cleaner Production Applied in a Small Furniture Industry in Brazil: Addressing Focused Changes in Design to Reduce Waste. Sustainability 2017, 9, 1867. [CrossRef]

23. Caetano, M.D.D.E.; Depizzol, D.B.; Reis, A.D.O.P.D. Análise do gerenciamento de resíduos sólidos e proposição de melhorias: Estudo de caso em uma marcenaria de Cariacica, ES. Gest. Prod. 2017, 24, 382-394. (In Portuguese) [CrossRef]

24. Daian, G.; Ozarska, B. Wood waste management practices and strategies to increase sustainability standards in the Australian wooden furniture manufacturing sector. J. Clean. Prod. 2009, 17, 1594-1602. [CrossRef]

25. Tong, R.; Zhang, L.; Yang, X.; Liu, J.; Zhou, P.; Li, J. Emission characteristics and probabilistic health risk of volatile organic compounds from solvents in wooden furniture manufacturing. J. Clean. Prod. 2019, 208, 1096-1108. [CrossRef]

26. Leite, P.P.S.; Pimenta, H.C.D. Environmental and Economic Benefits from the Cleaner Production Implementation within Furniture Manufacture from Natal-RN. Holos 2011, 2, 52-71. [CrossRef]

27. Massote, C.H.R.; Santi, A.M.M. Implementation of a cleaner production program in a Brazilian wooden furniture factory. J. Clean. Prod. 2013, 46, 89-97. [CrossRef]

28. Lins, P.S.; Cunha, R.D.A.; Kiperstok, A.; Rapôso, Á.L.Q.R.S.; César, S.F. Opportunities for Cleaner Production (CP) Using Process Flow Analysis: Case Study of a Furniture Manufacturer in the City of Palhoça (SC, Brazil). Sustainability 2020, 12, 863. [CrossRef]

29. Rapôso, A.; César, S.F.; Kiperstok, A. Design do Ciclo de Vida do Produto e Produção mais Limpa: Uma reflexão aplicada à produção de estofados. Rev. Estud. Des. 2013, 21, 1-25. (In Portuguese) [CrossRef]

30. Prado, M.V. Brasil Móveis. Relatório Setorial da Indústria de Móveis no Brasil 2018; IEMI/ABIMÓVEL: São Paulo, Brasil, 2018. (In Portuguese)

31. Prado, M.V. Brasil Móveis. Relatório Setorial da Indústria de Móveis no Brasil 2020; IEMI/ABIMÓVEL: São Paulo, Brasil, 2020. (In Portuguese)

32. Brainer, M.S.D.C.P.; Setor Moveleiro: Aspectos gerais e tendências no Brasil e na área de atuação do BNB. Caderno Setorial ETENE, Year 3, 34, June 2018. Available online: https:/ / www.bnb.gov.br/documents/80223/3585904/moveis_34-2018.pdf/f0e0 657f-a6c2-db33-f139-04d95692453e (accessed on 3 May 2021). (In Portuguese)

33. Brainer, M.S.D.C.P.; Setor Moveleiro: Aspectos gerais e tendências no Brasil e na área de atuação do BNB. Caderno Setorial ETENE, Year 4, 89, July 2019. Available online: https://www.bnb.gov.br/docments/80223/5577175/89_moveis.pdf/24f1422b-f8 08-7285-d724-eaf5a6bc2c48 (accessed on 18 May 2021). (In Portuguese) 
34. Moreira, J.M.M.Á.P.; Santos Filho, J.I. Setor Moveleiro como Parte Integrante da Cadeia Produtiva Florestal de Florestas Plantadas na Região de São Bento do Sul em Santa Catarina; Embrapa Florestas: Colombo, Brazil, 2020. Available online: https://www. infoteca.cnptia.embrapa.br/infoteca/bitstream/doc/1124779/1/Livro-Doc-341-1807-final-3.pdf (accessed on 19 June 2021). (In Portuguese)

35. Ministério da Agricultura, Pecuária e Abastecimento (MAPA). Plano Nacional de Desenvolvimento de Florestas Plantadas (PlantarFlorestas); Ministério da Agricultura, Pecuária e Abastecimento: Brasília, Brazil, 2018. Available online: https: / / www.embrapa.br/documents/10180/0/Plano+Nacional+de+Desenvolvimento+de+Florestas+Plantadas/90e38846-d556 -da1d-0213-dda16a75088e (accessed on 19 June 2021). (In Portuguese)

36. Instituto Brasileiro de Geografia Estatística (IBGE). Available online: https://concla.ibge.gov.br/busca-online-cnae.html?view= classe\&tipo $=$ cnae\&versao=7.0.0\&classe $=31012 \&$ chave $=$ marcenaria (accessed on 19 June 2021). (In Portuguese)

37. Cecchetti, F.; Razera, D.L. Design de Superfície na Indústria Brasileira de Móveis Planejados. ModaPalavra e-periódico 2018, 11, 21-43, UDESC 2018. Available online: https:/ / www.revistas.udesc.br/index.php/modapalavra/article/view / $10367 / 7183$ (accessed on 19 June 2021). (In Portuguese) [CrossRef]

38. Linkosalmi, L.; Husgafvel, R.; Fomkin, A.; Junnikkala, H.; Witikkala, T.; Kairi, M.; Dahl, O. Main factors influencing greenhouse gas emissions of wood-based furniture industry in Finland. J. Clean. Prod. 2016, 113, 596-605. [CrossRef]

39. Schneider, V.E.; Nehme, M.C.; Ben, F. Pólo Moveleiro da Serra Gaúcha: Sistemas de Gerenciamento Ambiental na Indústria Moveleira; Educs: Caxias do Sul, Brazil, 2006; p. 19. (In Portuguese)

40. Vieira, L.C.; Amaral, F.G. Barriers and strategies applying Cleaner Production: A systematic review. J. Clean. Prod. 2016, 113, 5-16. [CrossRef]

41. Oliveira Neto, G.C.; Leite, R.R.; Shibao, F.Y.; Lucato, W.C. Framework to overcome barriers in the implementation of cleaner production in small and médium-sized enterprises: Multiple case studies in Brazil. J. Clean. Prod. 2017, 142, 50-62. [CrossRef]

42. Associação Brasileira de Normas Técnicas. ABNT NR-25: Resíduos Industriais; Associação Brasileira de Normas Técnicas: Rio de Janeiro, Brazil, 2011. (In Portuguese)

43. Backes, A.; Nuske, M.A.; Konrath, G.C.S.; Thesing, N.J. Desenvolvimento sustentável na indústria moveleira: Um estudo multicaso na região noroeste do RS. Holos 2018, 3, 135-151. (In Portuguese) [CrossRef]

44. Panameño, R.; Aguilar, C.M.G.; Angel, B.E.; César, S.F.; Kiperstok, A. Cleaner Production and LCA as Complementary Tools in Environmental Assessment: Discussing Tradeoffs Assessment in a Case of Study within the Wood Sector in Brazil. Sustainability 2019, 11, 5026. [CrossRef]

45. Kravchenko, G.A.; Pasqualetto, A.; Ferreira, E.d.M. Aplicação de princípios da ecologia industrial nas empresas moveleiras de Goiás. Revista Engenharia Sanitária Ambiental 2016, 21, 283-294. (In Portuguese) [CrossRef]

46. Nunes, J.R.R.; Silva, J.E.A.R.D.; Moris, V.A.D.S.; Giannetti, B.F. Cleaner production in small companies: Proposal of a management methodology. J. Clean. Prod. 2019, 218, 357-366. [CrossRef]

47. Tseng, M.L.; Lin, Y.H.; Chiu, A.S.F. Fuzzy AHP-based study of cleaner production implementation in Taiwan PWB manufacturer. J. Clean. Prod. 2009, 17, 1249-1256. [CrossRef]

48. Jabbour, A.B.L.d.S.; Arantes, A.F.; Jabbour, C.J.C. Gestão ambiental em cadeias de suprimentos: Perspectivas atuais e futuras de pesquisa. Interciencia 2013, 38, 104-111. Available online: https: / www.redalyc.org/articulo.oa?id=33926950002 (accessed on 28 September 2020). (In Portuguese).

49. Xiong, X.; Ma, Q.; Yuan, Y.; Wu, Z.; Zhang, M. Current situation and key manufacturing considerations of green furniture in China: A review. J. Clean. Prod. 2020, 267, 121957. [CrossRef]

50. Olivério, J.L. Projeto de Fábrica Produtos Processos e Instalações Industriais, 1st ed.; IBLC-Instituto Brasileiro do Livro Científico Ltda.: São Paulo, Brazil, 1985; pp. 192-216. (In Portuguese)

51. Villar, A.D.M.; Nóbrega Júnior, C.L. Planejamento das Instalações Empresariais; Editora UFPB: João Pessoa, Brazil, 2014. Available online: http://www.editora.ufpb.br/sistema/press5/index.php/UFPB/catalog/view/548/420/1851-1 (accessed on 28 September 2020). (In Portuguese)

52. Muther, R. Planejamento Do Layout: Sistema SLP, 1st ed.; Edgard Blucher LTDA: São Paulo, Brazil, 1978. (In Portuguese)

53. Yang, T.; Su, C.; Hsu, Y. Systematic layout planning: A study on semiconductor wafer fabrication facilities. Int. J. Oper. Prod. Manag. 2000, 20, 1359-1371. [CrossRef]

54. Silva, J.M.N.D.; Farias, L.M.S.; Silva, E.G.D.; Silva, T.M.D.; Costa, A.N.D.M. Análise tecnicista dos movimentos: Proposta de arranjo físico geral para uma indústria de confecção de Campina Grande-PB. In Proceedings of the XXXIV Encontro Nacional de Engenharia de Producao, Infraestrutura e Desenvolvimento Sustentável: A Agenda Brasil+10, Curitiba, Brazil, 7-10 October 2014. (In Portuguese) [CrossRef]

55. Amaral, L.; Cezimbra, G.; Rodrigues, E.F.; Magarian, L.C.; Tsuji, E.R.; Deliberador, L.R.; Formigoni, A. O papel do arranjo físico e da gestão de informações como ferramenta para melhoria da competitividade e desempenho dos processos de uma lavanderia industrial. Rev. Metrop. Sustentabilidade 2012, 2, 48-63. Available online: https://revistaseletronicas.fmu.br/index.php/rms/ article/view /193/pdf (accessed on 28 September 2020). (In Portuguese)

56. Dias, I.C.P.; Gonçalves, M.C. Proposta de um novo layout para o arranjo físico: Uma aplicação do método SLP (Systematic Layout Planning) em uma microempresa no estado do Pará. VI Encontro Para. Eng. Produção (EPAEP) 2015, 1-12. (In Portuguese)

57. Prasetyo, V.E.; Belleville, B.; Ozarska, B.; Mo, J.P.T. A wood recovery assessment method comparison between batch and cellular production systems in the furniture industry. Smart Sustain. Manuf. Syst. 2019, 3, 1-17. [CrossRef] 
58. Sutcu, A.; Tanritanir, E.; Durmusoglu, B.; Koruca, H. An integrated methodology for layout design and work organisation in a furniture manufacturing plant. S. Afr. J. Ind. Eng. 2011, 22, 183-197. [CrossRef]

59. Silva, A.N.; Araújo, A.V.; Godoy, L.C.; Minette, L.J.; Suzuki, J.A. Contribution of computational simulation for layout analysis in a wooden furniture industry. Rev. Árvore 2017, 41. [CrossRef]

60. Silva, P.M.S.; Silva, A.A.da; Souza, P.F.; Campos, R.d.C.L. Layout optimization: A case study in a carpentry. ForScience 2014, 2 , 24-30. [CrossRef]

61. Fiedler, N.C.; Wanderley, F.B.; Nogueira, M.; Oliveira, J.T.D.S.; Guimarães, P.P.; Alves, R.T. Layout optimization of joineries in southern Espirito Santo state based on ergonomic and productivity parameters. Rev. Árvore 2009, 33, 161-170. [CrossRef]

62. Coleone, M.; Fróes, N.J.M. Uma proposta de melhoria no arranjo físico de uma fábrica do setor têxtil. Gepros 2019, 14, 98. Available online: https:/ / revista.feb.unesp.br/index.php/gepros/article/view/2608 (accessed on 28 September 2020). (In Portuguese) [CrossRef]

63. Serviço Brasileiro de Apoio às Micro e Pequenas Empresas. SEBRAE. Available online: https://www.sebrae.com.br/ sites/PortalSebrae/estudos_pesquisas/quem-sao-os-pequenos-negociosdestaque5,7f4613074c0a3410VgnVCM1000003b74010 aRCRD (accessed on 19 June 2021). (In Portuguese)

64. Brasil. Lei Complementar Federal n 123, of december, 14, 2006. Brasília, DF, Brazil, 2006. Available online: http:/ /www.planalto. gov.br/ccivil_03/Leis/LCP/Lcp123.htm (accessed on 31 May 2021). (In Portuguese)

65. Associação Brasileira de Normas Técnicas. ABNT. NR-23: Proteção Contra Incêndios; Associação Brasileira de Normas Técnicas: Rio de Janeiro, Brazil, 2011. (In Portuguese)

66. Associação Brasileira de Normas Técnicas. ABNT NR-24: Condições Sanitárias e de Conforto no Local de Trabalho; Associação Brasileira de Normas Técnicas: São Paulo, Brazil, 2019. (In Portuguese) 